\title{
Ethiopia's Growth and Transformation Plan: A Computable General Equilibrium Analysis of Alternative Financing Options
}

Ermias Engida, Seneshaw Tamru, Eyasu Tsehaye, Dario Debowicz, Paul Dorosh, and Sherman Robinson

Development Strategy and Governance Division, International Food Policy Research Institute - Ethiopia Strategy Support Program II, Ethiopia

Ethiopia Strategy Support Program II (ESSP II)

ESSP II Working Paper 30

November 2011

IFPRI-ADDIS ABABA

P.O. Box 5689

Addis Ababa, Ethiopia

Tel: +251-11-646-2921

Fax: +251-11-646-2318

E-mail: ifpri-addis@cgiar.org

http://essp.ifpri.info/
IFPRI HEADQUARTERS

International Food Policy Research Institute

2033 K Street, NW • Washington, DC 20006-1002

USA

Tel: +1-202-862-5600

Skype: IFPRIhomeoffice

Fax: +1-202-467-4439

E-mail: ifpri@cgiar.org

http://www.ifpri.org 


\title{
THE ETHIOPIA STRATEGY SUPPORT PROGRAM II (ESSP II) WORKING PAPERS
}

\author{
ABOUT ESSP II \\ The Ethiopia Strategy Support Program II is an initiative to strengthen evidence-based policymaking \\ in Ethiopia in the areas of rural and agricultural development. Facilitated by the International Food \\ Policy Research Institute (IFPRI), ESSP II works closely with the government of Ethiopia, the \\ Ethiopian Development Research Institute (EDRI), and other development partners to provide \\ information relevant for the design and implementation of Ethiopia's agricultural and rural \\ development strategies. For more information, see http://www.ifpri.org/book- \\ 757/ourwork/program/ethiopia-strategy-support-program or http://essp.ifpri.info/ or \\ http://www.edri.org.et/.
}

\section{ABOUT THESE WORKING PAPERS}

The Ethiopia Strategy Support Program II (ESSP II) Working Papers contain preliminary material and research results from IFPRI and/or its partners in Ethiopia. The papers are not subject to a formal peer review. They are circulated in order to stimulate discussion and critical comment. The opinions are those of the authors and do not necessarily reflect those of their home institutions or supporting organizations.

\section{About the Author(s)}

Ermias Engida: Research Officer, Ethiopia Strategy Support Program II, International Food Policy Research Institution (IFPRI)

Seneshaw Tamru: Research Officer, Ethiopia Strategy Support Program II, International Food Policy Research Institution (IFPRI)

Eyasu Tsehaye: Junior Researcher, Macro Department, Ethiopian Development Research Institute (EDRI)

Dario Debowicz: Postdoctoral Fellow, Development Strategy and Governance Division, International Food Policy Research Institution (IFPRI)

Paul Dorosh: Division Director, Development Strategy and Governance Division, International Food Policy Research Institution (IFPRI)

Sherman Robinson: Senior Research Fellow, Environment and Production Technology Division, International Food Policy Research Institution (IFPRI) 


\title{
Ethiopia's Growth and Transformation Plan: A Computable General Equilibrium Analysis of Alternative Financing Options
}

\author{
Ermias Engida, Seneshaw Tamru, Eyasu Tsehaye, Dario Debowicz, \\ Paul Dorosh, and Sherman Robinson
}

Development Strategy and Governance Division, International Food Policy Research Institute - Ethiopia Strategy Support Program II, Ethiopia 


\section{Table of Contents}

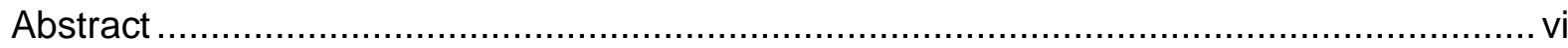

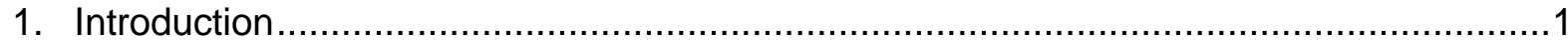

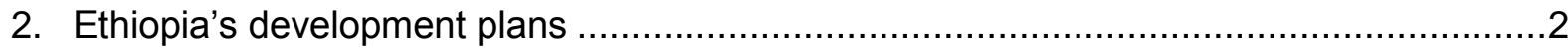

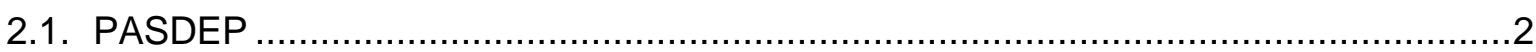

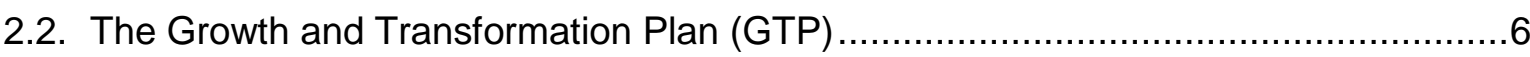

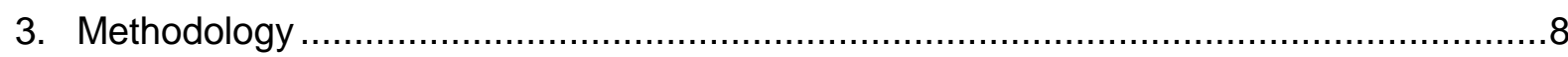

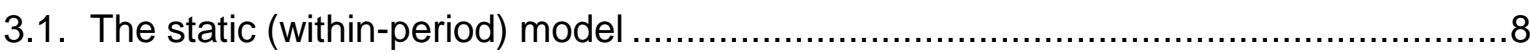

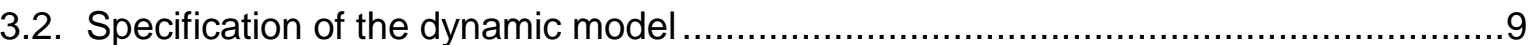

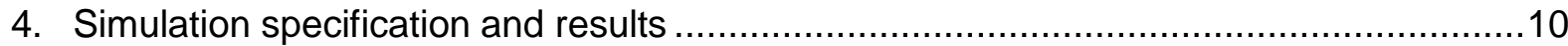

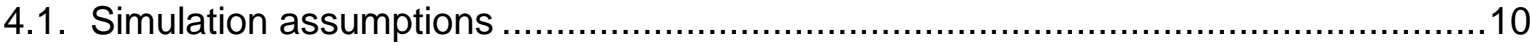

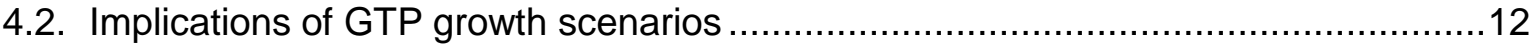

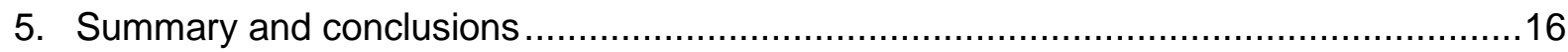

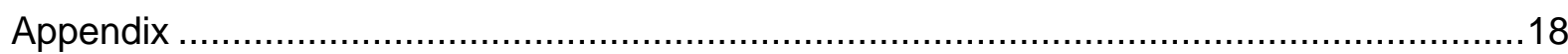

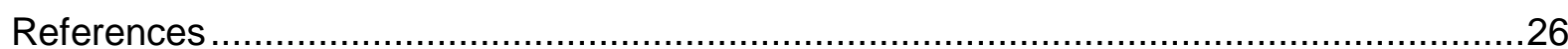




\section{List of Tables}

Table 2.1. GDP growth by sector under PASDEP (2005/06-2009/10) .2

Table 2.2. Composition of GDP under PASDEP (2004/05-2009/10), (percent of total GDP) 3

Table 2.3. Government plan and actual revenue and expenditure (\% of GDP), 2009/10 .......3

Table 2.4. Ethiopia's net primary school enrollment (\%): 1991-2007, compared to other countries in the region ..........................................................................

Table 2.5. GDP growth target (\%) of the GTP under the medium growth scenario ...............6

Table 2.6. GDP growth target (\%) of the GTP under the high growth scenario .....................7

Table 2.7. GTP targets for general government resource mobilization ( $\%$ of GDP) ...............7

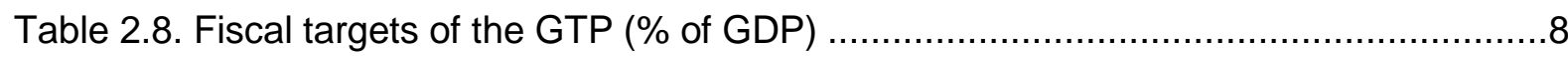

Table 4.1. Simulation specific assumptions ...............................................................11

Table 4.2. Average annual TFP growth rates (\%), 1990-2008......................................12

Table 4.3. Simulation results: macro-economic variables ................................................13

Table 4.4. Simulation results: factor incomes............................................................. 14

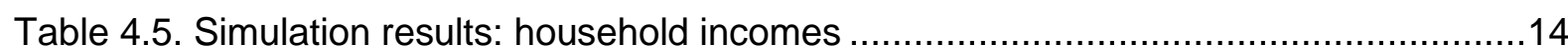

Table 4.6. Simulation results: household expenditures ..................................................16

\section{List of Figures}

Figure 2.1. Ethiopia: Percent of the population connected to an urban agglomeration 4

Figure 2.2. Percent of the population by travel time to urban agglomerations of 50,000

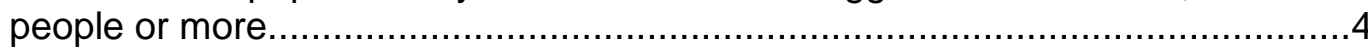

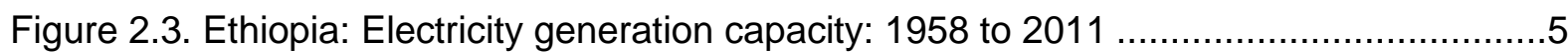

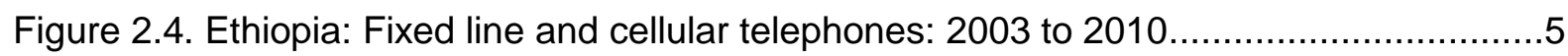

Figure 4.1. Simulation results: household incomes .......................................................15

\section{List of Appendices}

Appendix A.1. Specification of the CGE and micro-simulation model adapted from Dorosh and Thurlow (2009) ...................................................................... 18

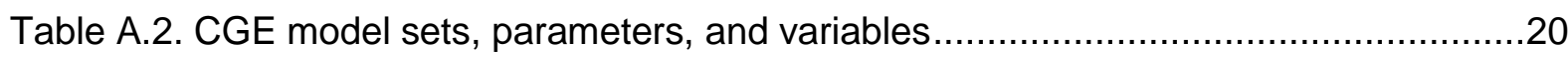

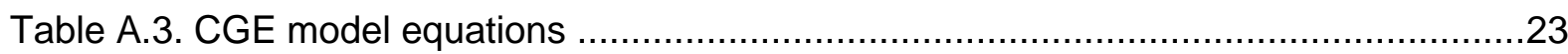




\begin{abstract}
Under the Plan for Accelerated and Sustained Development to End Poverty (PASDEP), implemented from 2005/06 to 2009/10, Ethiopia achieved rapid economic growth and laid a foundation for future growth by making substantial investments in infrastructure and human capital. The Growth and Transformation Plan (GTP) for 2010/11-2014/15, Ethiopia's new five year plan, sets even higher growth and investment targets. This paper analyzes these new GTP investment and growth targets using a Computer General Equilibrium (CGE) model of the Ethiopian economy to assess the implications of the plan on sectoral growth and household incomes.
\end{abstract}

The analysis of the GTP investment plan indicates that achieving its high growth targets will require rapid increases in total factor productivity and large-scale mobilization of domestic and foreign savings. The 4.9 percent annual Total Factor Productivity (TFP) growth needed to reproduce the high Gross Domestic Product (GDP) growth under PASDEP (2005/06 to $2009 / 10$ ) or to continue this growth into the future is very high in comparison to those that have been achieved in other fast-growing economies such as India, China, and Indonesia. Achieving the GTP target GDP growth rates requires even higher TFP growth: by 5.8 and 7.6 percent per year respectively in the medium and high growth GTP scenarios. To some extent, some of this productivity growth could be achieved through reduced underemployment. Nonetheless, these results suggest that the projected GDP growth outcomes are very optimistic.

Meeting the financing requirements for the GTP will also be challenging given the large amount that needs to be mobilized, as compared to the low historical savings in Ethiopia. In the model simulations where the additional finance is mobilized from domestic sources, household savings rates increase from an average of 5.5 percent of total household income in 2014/15 in the base case to 12.5 percent of total household income in 2014/15 in the increased household savings / medium case scenario. Achieving this high rate of domestic savings would also require changes in macroeconomic policy, such as increases in tax rates or increases in interest rates to encourage private savings. If the additional finance is mobilized through increased foreign borrowing or transfers, foreign savings would need to increase from 47.7 billion birr in 2014/15 of the base case to 96.8 billion birr in 2014/15 of the medium case scenario in real terms (i.e. from 7.5 to 14.8 percent of GDP).

Regardless of the financing strategy, the high TFP and GDP growth rates under the GTP imply high average income growth for both poor and rich households, in both rural and urban areas. Because the GTP involves a greater concentration of investment in non-agricultural sectors than did PASDEP, growth of incomes of urban households is higher in the GTP than under PASDEP. Conversely, income growth of the rural poor is slightly lower under the medium growth scenario with domestic savings (10.0 percent) than under a continuation of PASDEP growth and investment (10.6 percent).

Thus, this analysis shows that if the GTP investment and sectoral growth targets are achieved, real incomes of the poor in Ethiopia would rise substantially. The base simulations indicate that real incomes of the poor rose under PASDEP from 2005/06 to 2010/11. Under GTP, this real income growth would be accelerated, provided there is sufficient foreign savings or mobilization of domestic savings to achieve the targets. Nonetheless, the simulations also suggest that agricultural growth will still be crucial for raising incomes of Ethiopia's rural poor. Thus, investments that raise agricultural productivity will need to continue in order to ensure that the rural poor share in the substantial projected benefits that would result from achieving the high economic growth targets of the GTP. 


\section{Introduction}

Countries devise and implement medium term development plans to articulate a development strategy that will provide the guiding framework for implementation of policies. Accordingly, the Ethiopian government has been designing and implementing strategies and plans to manage the overall development of the country and achieve its key objective of broad-based, accelerated, and sustained economic growth so as to eradicate poverty. During the last development plan, the Plan for Accelerated and Sustained Development to End Poverty (PASDEP): 2005/06-2009/10, the country achieved remarkable economic and social development.

Based on its experience with implementation of PASDEP, the government has formulated the next five year plan, the Growth and Transformation Plan (GTP), for 2010/11-2014/15. The GTP is envisaged to sustain rapid and broad based economic growth and contribute to Ethiopia's goal of becoming a middle-income economy by 2020-2023. Economic growth and other development targets set in the GTP are even higher than those in PASDEP and earlier plans. Achieving these targets, however, will require very large productivity growth and huge amounts of financial resources anticipated to be sourced from increased domestic saving mobilization, foreign direct investment, and foreign borrowing.

Despite the huge resource requirements of the GTP, the government's Medium Term macroeconomic fiscal Framework (MTF) envisages modest spending and revenue growth during the same period: 2010/11-2014/15. Much of the development spending is planned to be "off-budget" (i.e. not included in the general government spending) through domestic and foreign resource mobilization of public development enterprises. The participation of the private sector in savings mobilization and investment is acknowledged to be important in the GTP, but the private sector's role in financing is not explicitly stated or quantified.

The basic objective of this study is to assess the implications of alternative financing options of the GTP. Using a computable general equilibrium (CGE) model of the Ethiopian economy, this study provides quantitative estimates of the impacts of planned GTP investments on various economic indicators, including overall GDP, real exchange rates, sectoral output, household income levels, and household expenditures. In particular, the study focuses on two major financing alternatives: increased domestic (household) savings and increased foreign savings (through foreign borrowing, foreign direct investment, or foreign grants).

Section 2 presents a brief overview of the implementation of the previous five year plan (PASDEP), examining both macro-economic indicators as well as investments in infrastructure designed to build a foundation for further economic growth. It also briefly introduces the GTP and the broad economic targets. Section 3 describes the CGE model and the data base used for the analysis (with details of the model equations included in an Appendix). Simulation results are discussed in Section 4. Section 5 contains the summary and conclusions. 


\section{Ethiopia's development plans}

Since the first Structural Adjustment Program (SAP) of Ethiopia (1993-1996), the Ethiopian Government has implemented various development plans designed to promote broad-based and equitable economic growth and to eradicate poverty. The development plan for 2005/06-2009/10, the Plan for Accelerated and Sustained Development to End Poverty (PASDEP), was aimed at achieving all the Millennium Development Goal (MDG) targets and the government's vision for Ethiopia's development.

\subsection{PASDEP}

In PASDEP, two alternative economic growth scenarios were considered. In the base case scenario, an average economic growth rate of 7 percent per annum was considered necessary to achieve the MDGs. For the high case scenario, which aimed beyond achieving MDG's targets, a 10 percent annual average economic growth target was set.

During the time of PASDEP's implementation, substantial economic growth and significant progress on social and human development were achieved. Annual average GDP growth is estimated at 11 percent (MOFED 2010) which exceeded both the base case and high growth scenarios set in PASDEP (Table 2.1). Specifically, average annual growth rates in the agricultural and services sectors (8.4 percent and 14.6 percent, respectively) exceeded plan targets. However, growth in the industrial sector, though substantial (10.0 percent per year), fell short of both the base case (11.0 percent growth) and high case (18.0 percent growth) targets.

Table 2.1. GDP growth by sector under PASDEP (2005/06-2009/10)

\begin{tabular}{|c|c|c|c|c|}
\hline \multirow[t]{2}{*}{ Sector } & \multicolumn{2}{|c|}{$\begin{array}{c}\text { Planned Average Growth } \\
(2005 / 06-2009 / 10)\end{array}$} & \multirow{2}{*}{$\begin{array}{c}\text { Achieved Average } \\
\text { Growth } \\
(2005 / 06-2009 / 10)\end{array}$} & \multirow{2}{*}{$\begin{array}{c}\text { Percentage share } \\
\text { of GDP } \\
(2009 / 10)\end{array}$} \\
\hline & Base Case & High Case & & \\
\hline GDP & 7.0 & 10.0 & 11.0 & 100.0 \\
\hline Agriculture & 6.0 & 6.4 & 8.4 & 41.6 \\
\hline Industry & 11.0 & 18.0 & 10.0 & 12.9 \\
\hline Services & 7.0 & 10.3 & 14.6 & 45.5 \\
\hline
\end{tabular}

Source: MOFED (2010)

The structure of aggregate demand changed very little during the PASDEP period: the share of consumption expenditure at the end of the PASDEP was the same as the level in 2004/05 (94 percent, Table 2.2). The share of gross capital formation (investment) in GDP declined slightly, from 23.8 to 22.3 percent. Most of this investment was financed from foreign sources (reflected in the resource balance, the difference between exports and imports of goods and services), which equaled 19.3 percent of GDP in 2009/10. The domestic savings rate also remained unchanged in the plan period in spite of a plan to increase the domestic saving $^{1}$ rate to 13.1 percent. At the end of the PASDEP period, the domestic savings rate was only 5.5 percent.

\footnotetext{
${ }^{1}$ Unlike the UN System of National Accounts, which defines savings as income net of consumption (income - consumption), domestic savings in PASDEP and GTP is defined as domestic product net of consumption (GDP - consumption). As a net recipient of transfers from the rest of the world, Ethiopia's savings rate is therefore underestimated in PASDEP and GTP by the amount equivalent to the net income and current transfers residents receive from the rest of the world.
} 
Table 2.2. Composition of GDP under PASDEP (2004/05-2009/10), (percent of total GDP)

\begin{tabular}{lrrrrrr}
\hline \multicolumn{1}{c}{ Item } & $\mathbf{2 0 0 4 / 0 5}$ & $\mathbf{2 0 0 5 / 0 6}$ & $\mathbf{2 0 0 6 / 0 7}$ & $\mathbf{2 0 0 7 / 0 8}$ & $\mathbf{2 0 0 8 / 0 9}$ & \multicolumn{2}{c}{$\mathbf{2 0 0 9 / 1 0}$} \\
\hline Total Consumption & 94.1 & 95.4 & 91.3 & 94.8 & 93.6 & 94.4 \\
Gross Capital Formation & 23.8 & 25.2 & 22.1 & 22.4 & 22.7 & 22.3 \\
Exports of Goods and Services & 15.1 & 13.8 & 12.7 & 11.4 & 10.5 & 13.6 \\
Imports of Goods and Services & 35.5 & 36.5 & 32 & 30.8 & 28.7 & 33 \\
Resource Balance & -20.4 & -22.7 & -19.3 & -19.4 & -18.2 & -19.3 \\
Gross Domestic Saving & 5.9 & 4.6 & 8.7 & 5.3 & 6.7 & 5.5 \\
\hline
\end{tabular}

Source: MOFED (2010)

One reason for this low domestic savings rate was weak resource mobilization by the government from tax and non-tax sources. In the PASDEP, government revenue from domestic sources was targeted to grow at an average annual rate of 20 percent. In fact, the government's domestic revenue during 2005/06-2009/10 grew at an average rate of 26 percent (MOFED 2010). However, this growth was largely due to general inflation, which averaged 18 percent per year. In real (inflation-adjusted) terms, government domestic revenue increased by an average rate of only about 7 percent per year, and government's revenue as a share of GDP marginally declined during the PASDEP period, and was only 14.0 percent in $2009 / 10$.

Table 2.3. Government plan and actual revenue and expenditure (\% of GDP), 2009/10

\begin{tabular}{lrr} 
& 2009/10 Target & 2009/10 Actual \\
\hline Domestic Revenue & $18.7 \%$ & $14.0 \%$ \\
Expenditure & $27.0 \%$ & $18.6 \%$ \\
\hline
\end{tabular}

Source: MOFED (2010)

The public and private investments during the five years of PASDEP resulted in substantial increases in physical infrastructure and human capital that have laid a foundation for further growth and poverty reduction. Road and telecommunications infrastructure have increased dramatically, greatly increasing the proportion of Ethiopia's population with access to urban markets and services.

In 1984, only about 6 million people in Ethiopia (12 percent of the population) were within 3 hours travel time to an urban center (agglomeration) with a population of at least 50 thousand (Figure 2.1). By 1997 this figure had doubled to about 12 million people. In 2007, this figure had reached 38 million people (over half of Ethiopia's population) because of major investments in roads and to a lesser extent, increased rural-urban migration. These investments also reduced remoteness: the number of people who lived more than 10 hours from an urban center of more than 50,000 people fell from 40 percent in 1984 to only 12 percent in 2007 (Figure 2.2). Likewise, the percentage of people who lived more than 5 hours from a major urban center fell from 66 percent in 1994 to 38 percent in 2007, a level similar to that in Mozambique, though still about double the rate in densely populated (and more urbanized) Nigeria. 
Figure 2.1. Ethiopia: Percent of the population connected to an urban agglomeration

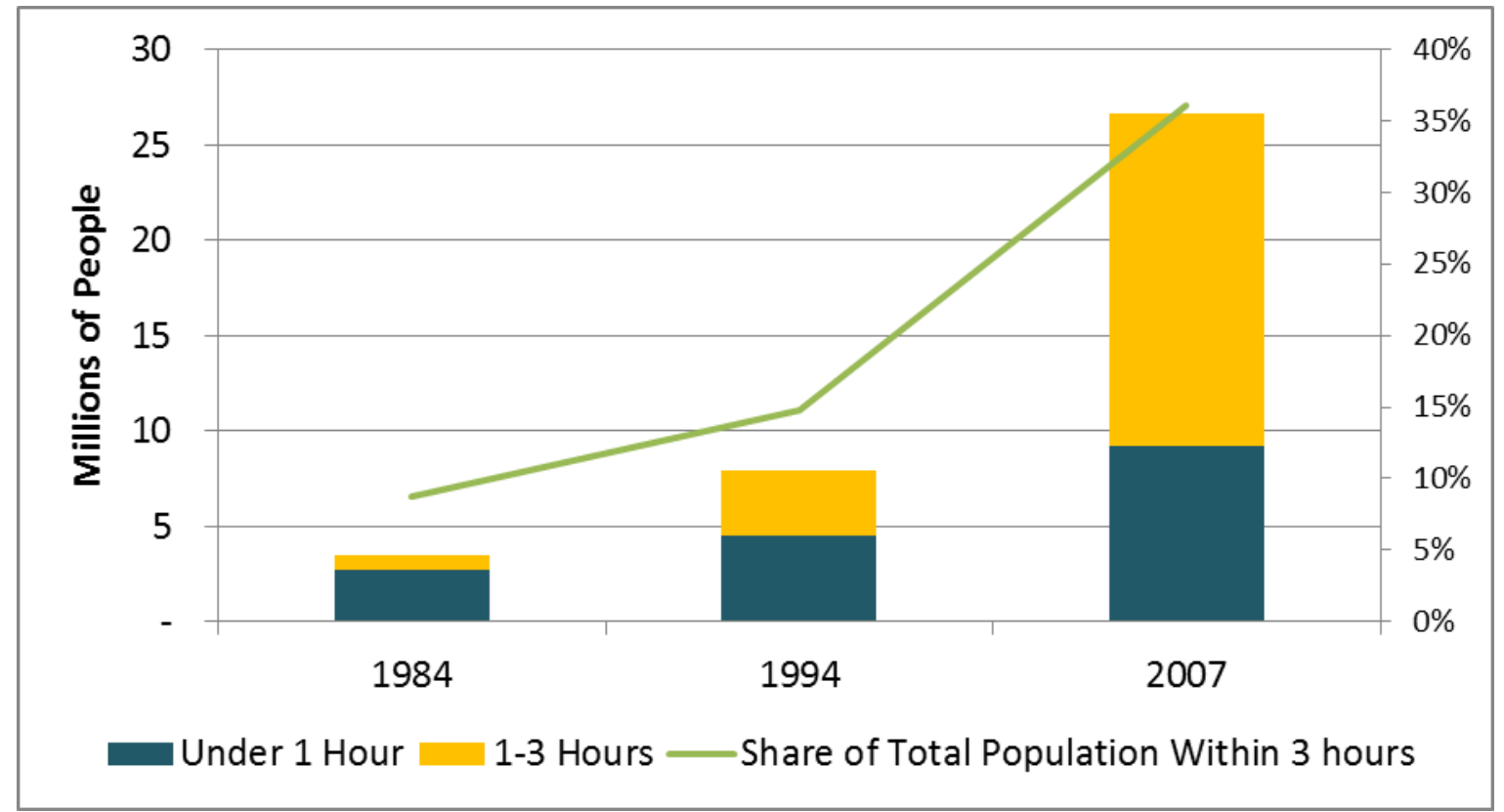

Source: Dorosh et al. (2011); Schmidt (2011).

Figure 2.2. Percent of the population by travel time to urban agglomerations of 50,000 people or more

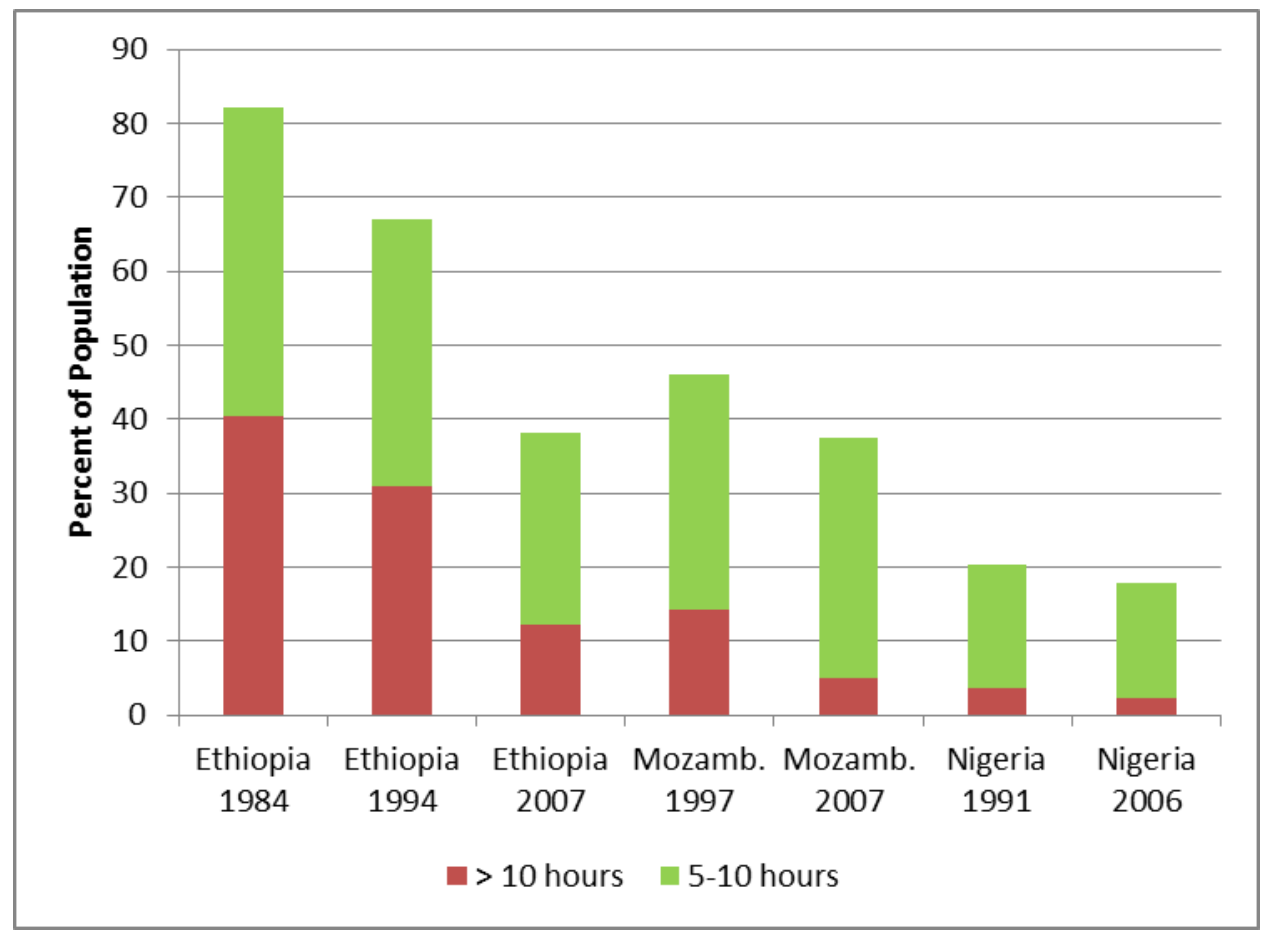

Source: Schmidt (2011); Cunguara et al. (forthcoming); Sackey et al. (forthcoming).

Note: Mozamb. = Mozambique

Massive investment in roads and increasing urbanization has been accompanied by large increases in electricity generation capacity. Building on a very low base of about 500 megawatts (about 7 kilowatts/person) in the early 2000 s, electricity generation capacity surged to about 750 megawatts in 2008 and is expected to reach about 1900 million megawatts (1.9 gigawatts) during the initial years of the GTP (Figure 2.3). As can be seen 
from Figure 2.4 telecommunications coverage has increased even more dramatically, with the number of land line connections increasing ten-fold between 2003 and 2010 and with about 10 million cell phones in the latter year.

Figure 2.3. Ethiopia: Electricity generation capacity: 1958 to 2011

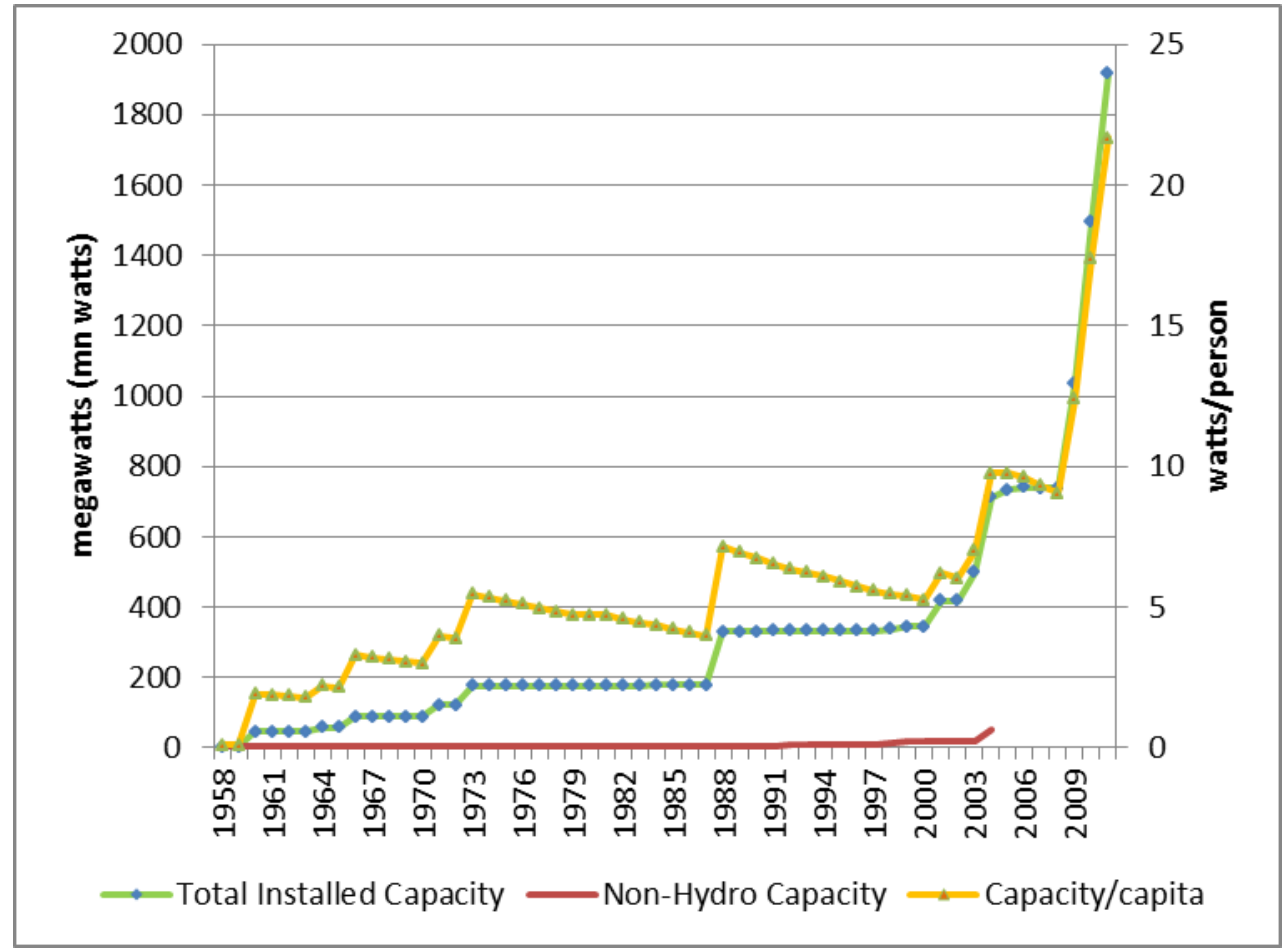

Source: Dorosh et al. (2011); Calculated using CSA Survey of Manufacturing (various years) and Ethiopian Electric Power Corporation data.

Notes: Figures for 2008-2010 based on additional capacity from Tekeze I (300 Mw) in 2009; and Tana Beles (460 Mw) in 2010. 2011 figures is 2010 figure plus Gile Gibe II (420 Mw) for which the tunnel collapsed in December, 2009.

Figure 2.4. Ethiopia: Fixed line and cellular telephones: 2003 to 2010

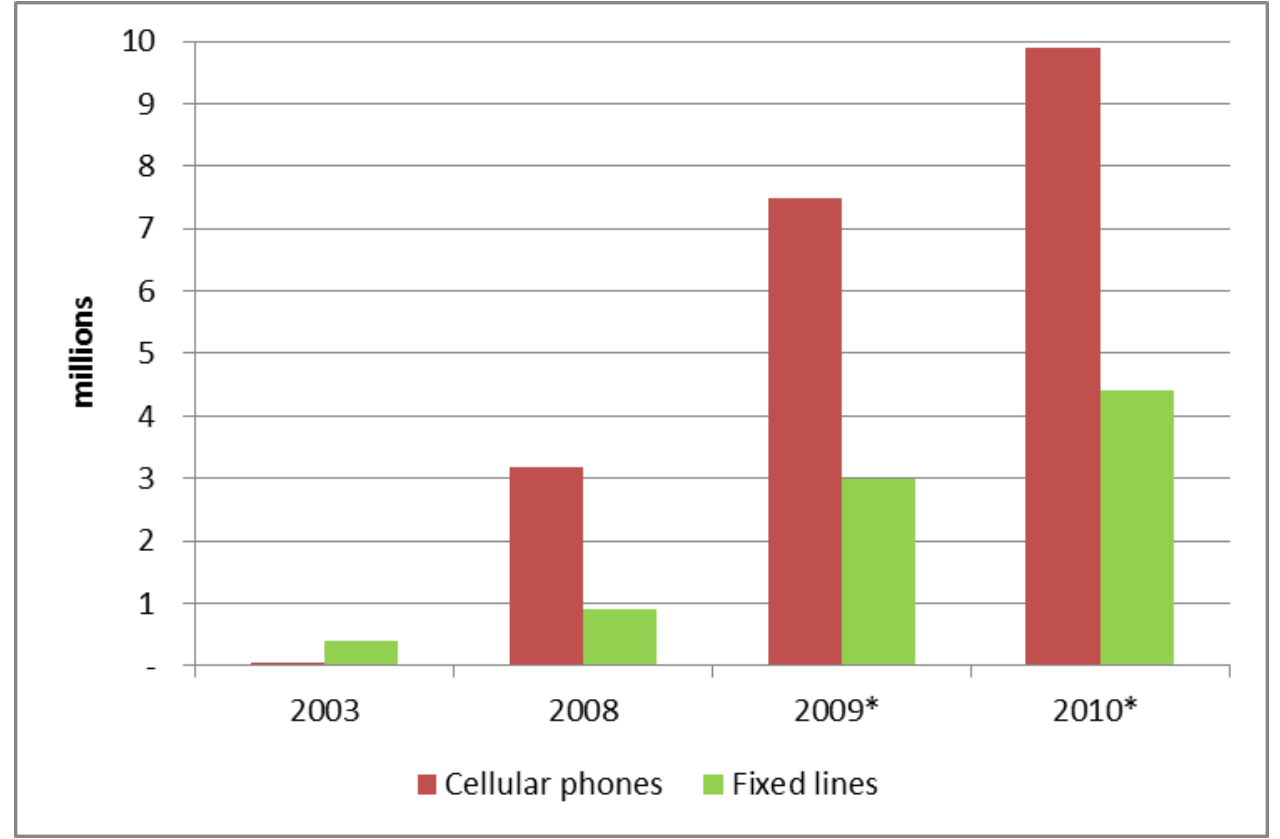

Sources: ITU (2009). Dorosh et al. (2011); Information Society Statistical Profiles 2009 - Africa, International Telecommunication Union (ITU). Ethiopian Telecommunications Corporation (ETC). ETC Strategic Plan. 
Finally, investments in education have resulted in major increases in primary school enrollment, with potential long term effects on household welfare and labor productivity. As shown in Table 2.4, in 1991 only 21.9 percent of Ethiopian primary school-aged children were enrolled in primary school (and only 18.8 percent of girls). By 2000, net primary school enrollment had almost doubled to 38.4 percent (32.5 percent for girls), and by 2007, these figures reached 71.4 percent for all children and 68.5 percent for girls. While net primary school enrollment in Ethiopia still lags behind that of most other eastern and southern African countries (an important exception is Sudan), the gap between Ethiopia and these countries has narrowed significantly.

Table 2.4. Ethiopia's net primary school enrollment (\%): 1991-2007, compared to other countries in the region

\begin{tabular}{|c|c|c|c|c|c|c|}
\hline & \multicolumn{3}{|c|}{ All Children } & \multicolumn{3}{|c|}{ Girls } \\
\hline & 1991 & 2000 & 2007 & 1991 & 2000 & 2007 \\
\hline Ethiopia & 21.9 & 38.4 & 71.4 & 18.8 & 32.5 & $\overline{68.5}$ \\
\hline Burundi & 53.0 & 42.6 & 81.2 & 48.8 & 38.8 & 80.3 \\
\hline Kenya & --- & 66.2 & 86.3 & --- & 67.1 & 86.3 \\
\hline Rwanda & 66.9 & --- & 93.6 & 65.0 & --- & 94.9 \\
\hline Sudan & --- & 41.2 & --- & --- & 37.2 & --- \\
\hline Uganda & 51.1 & --- & 94.6 & 46.2 & --- & 96.1 \\
\hline
\end{tabular}

Source: Dorosh et al. (2011); World Bank (2010)

\subsection{The Growth and Transformation Plan (GTP)}

The government has formulated the five year Growth and Transformation Plan (GTP) (2010/11-2014/15) to carry forward the important strategic directions pursued in the PASDEP. In addition to achieving the MDGs in the social sector and establishing suitable conditions for sustainable nation building, the GTP has a major objective of maintaining at least an average real GDP growth rate of 11 percent. By sustaining economic growth throughout the five year plan period, the government aims to achieve the MDG targets by 2015 and its longer term vision of being a middle income country by $2020-2023$.

GTP is unique in comparison to past development plans of the country due to its high economic growth and other development targets. Following MOFED, two growth scenarios are considered in the GTP: medium growth and high growth. Under the medium growth case scenario, Ethiopia's economy is projected to grow at a rate attained during PASDEP (11.2 percent), as shown in Table 2.5. All MDG targets will be met under this scenario.

Table 2.5. GDP growth target (\%) of the GTP under the medium growth scenario

\begin{tabular}{lcccccc}
\hline Sector & $\mathbf{2 0 1 0 / 1 1}$ & $\mathbf{2 0 1 1 / 1 2}$ & $\mathbf{2 0 1 2 / 1 3}$ & $\mathbf{2 0 1 3 / 1 4}$ & $\mathbf{2 0 1 4 / 1 5}$ & Average \\
\hline Agriculture & 8.5 & 8.5 & 8.6 & 8.6 & 8.7 & 8.6 \\
Industry & 14.0 & 17.9 & 21.4 & 23.0 & 23.7 & 20.0 \\
Services & 12.5 & 11.5 & 10.5 & 9.5 & 9.0 & 10.6 \\
Real GDP & $\mathbf{1 1 . 0}$ & $\mathbf{1 1 . 1}$ & $\mathbf{1 1 . 3}$ & $\mathbf{1 1 . 2}$ & $\mathbf{1 1 . 4}$ & $\mathbf{1 1 . 2}$ \\
\hline
\end{tabular}

Source: MOFED (2010)

Under the high growth scenario, an annual average GDP growth rate of 14.9 percent is targeted (see Table 2.6). The basic assumption for the high growth scenario is the doubling of agricultural value added, by scaling up the productivity of farmers to the productivity levels 
of existing best or model farmers (MOFED 2010). The GDP growth in the high growth scenario is thus significantly different from the growth in the medium growth scenario due to the large growth difference in the agriculture sector. The growth targets in the industry and service sectors in the high growth scenario are only slightly higher than in the medium growth case.

Table 2.6. GDP growth target (\%) of the GTP under the high growth scenario

\begin{tabular}{lcccccc}
\hline Sector & $\mathbf{2 0 1 0 / 1 1}$ & $\mathbf{2 0 1 1 / 1 2}$ & $\mathbf{2 0 1 2 / 1 3}$ & $\mathbf{2 0 1 3 / 1 4}$ & $\mathbf{2 0 1 4 / 1 5}$ & Average \\
\hline Agriculture & 9.5 & 13.5 & 16.1 & 17.1 & 18.4 & 14.9 \\
Industry & 14.8 & 19.4 & 20.8 & 23.7 & 27.9 & 21.3 \\
Services & 14.6 & 13.8 & 12.9 & 11.8 & 10.9 & 12.8 \\
Real GDP & 12.5 & 14.4 & 15.3 & 15.6 & 16.6 & 14.9 \\
\hline
\end{tabular}

Source: MOFED (2010)

According to the GTP, all the country's development policies and strategies are geared towards the main development agenda of poverty eradication. The GDP growth in the plan is expected to help create employment and raise income, contributing to poverty eradication. Poverty oriented government expenditure as a percentage of GDP are also set to grow from 12.3 percent in 2009/10 to 17.3 percent at the end of the plan period. Accordingly, the GTP aims to achieve a reduction of poverty from the estimated level of 29.2 percent in $2009 / 10$ to 22.2 percent in $2014 / 05^{2}$.

While sectoral and overall GDP growth outcomes as well as expenditure components of GDP in the GTP are projected in two scenarios, the rest of the social and infrastructural development outcomes and the government's fiscal operations are projected only in one (base-case) scenario. For achieving the objectives stated in the GTP, allocation of finances has been planned based on the Medium Term macroeconomic fiscal Framework (MTF).

According to the MTF, domestic revenue mobilization is to be boosted with the full implementation of the on-going tax reform, improvement in efficiency of tax administration, and broadening the tax base in line with the economic growth. As a result, tax collection as a percent of GDP is expected to rise from 11.3 percent in 2009/10 to 15 percent in 2014/15, as shown in the following table.

Table 2.7. GTP targets for general government resource mobilization (\% of GDP)

\begin{tabular}{lcccrrrr}
\hline Items & $\mathbf{2 0 0 9 / 1 0}$ & $\mathbf{2 0 1 0 / 1 1}$ & $\mathbf{2 0 1 1 / 1 2}$ & $\mathbf{2 0 1 2 / 1 3}$ & $\mathbf{2 0 1 3 / 1 4}$ & $\mathbf{2 0 1 4 / 1 5}$ & Average \\
\hline Domestic Revenue & 14.0 & 14.1 & 14.2 & 15.3 & 16.8 & 17.1 & 15.3 \\
Tax Revenue & 11.3 & 11.7 & 12.1 & 13.2 & 14.7 & 15.0 & 13.0 \\
Non-tax Revenue & 2.8 & 2.4 & 2.1 & 2.1 & 2.1 & 2.1 & 2.3 \\
Grants & 3.2 & 3.7 & 4.3 & 3.9 & 3.6 & 3.3 & 3.7 \\
\hline
\end{tabular}

Source: MOFED (2010)

Government expenditure during the GTP is planned to prioritize the financing of ongoing projects and investments in pro-poor ${ }^{3}$ sectors, is expected to be based on the growth prospects of the country in the coming years, and is aimed at maintaining the deficit at a sustainable level. As a result, the average government deficit in the GTP is planned to be only 2.3 percent of GDP, of which one third is to be covered by external borrowing (Table 2.8).

\footnotetext{
${ }^{2}$ The simulations in this paper show changes in average incomes of various household groups. Further work is planned to show changes in levels of poverty.

${ }^{3}$ According to the GTP, pro-poor expenditure includes spending on agriculture and food security, education, health, road and water.
} 
Table 2.8. Fiscal targets of the GTP (\% of GDP)

\begin{tabular}{lrrrrrrr}
\hline Items & $\mathbf{2 0 0 9 / 1 0}$ & $\mathbf{2 0 1 0 / 1 1}$ & $\mathbf{2 0 1 1 / 1 2}$ & $\mathbf{2 0 1 2 / 1 3}$ & $\mathbf{2 0 1 3 / 1 4}$ & $\mathbf{2 0 1 4 / 1 5}$ & $\begin{array}{c}\text { Average } \\
\mathbf{2 0 1 0 / 1 1 - 2 0 1 4 / 1 5}\end{array}$ \\
\hline Total Revenue and Grants & 17.3 & 17.8 & 18.4 & 19.2 & 20.4 & 20.4 & 19.2 \\
Total Expenditure & 18.6 & 20.5 & 20.2 & 21.1 & 22.3 & 23.7 & 21.6 \\
Deficit including Grants & 1.3 & 2.7 & 1.7 & 1.9 & 1.9 & 3.3 & 2.3 \\
$\quad$ External Net & 1.1 & 1.0 & 0.8 & 0.8 & 0.8 & 0.6 & 0.8 \\
$\quad$ Domestic Net & 0.5 & 1.6 & 0.9 & 1.1 & 1.2 & 2.7 & 1.5 \\
\hline
\end{tabular}

Source: MOFED (2010)

\section{Methodology}

CGE modeling is clearly an appropriate methodology to approach this problem, as it allows capturing the most relevant interactions in the economic system and, in particular, reflecting the effects of the different savings mechanisms under study on different parts of the economic system. Also, by representing the workings of the economy in a structural way, CGE modeling allows for an explicit reflection on the main transmission channels at work in the repercussion of the effects of these saving mechanisms.

The model used in this study is a recursive dynamic extension of the standard CGE model of the International Food Policy Research Institute (IFPRI), documented in Diao et al. (2011). This kind of dynamic model is based on the assumption that the behavior of economic agents (private and public) is characterized by adaptive expectations: economic agents make their decisions on the basis of past experiences and current conditions, with no role for forward-looking expectations about the future (Lofgren, Harris, and Robinson 2001). This is an alternative that captures developing countries' reality better than inter-temporal dynamic models that can be explained by economic agents who have forward looking (rational) expectations and make inter-temporally optimal decisions, in which everybody knows everything about the future, and they use that information in making decisions.

The model is solved recursively-one period at a time. Since a recursive model is a series of static CGE models that are linked between periods, the equations in this model are separated into a within-period module, which presents the decisions in each time period, and a between-period module, which governs the dynamics of the model.

\subsection{The static (within-period) model}

This part defines a single period static CGE model. The model assumes that producers maximize profits subject to production functions. In this model a multi-stage production technology is adopted. At the top level, value added and intermediate inputs are combined via a Constant Elasticity of Substitution (CES) production technology to produce gross output. Factors of production are substitutable, via the use of constant elasticity of substitution (CES) functions. On the other hand, the intermediate inputs are aggregated in a fixed proportion-Leontief specification.

The domestic output of each commodity is either domestically used or exported. Profit maximization drives producers to sell their products in domestic or foreign markets based on 
the potential returns. It is assumed that commodities sold domestically can only imperfectly be transformed into exportable commodities, via the use of constant elasticity of transformation (CET) functions. In an analogous way, the model incorporates imperfect substitutability between domestically produced and imported goods (i.e. Armington assumption).

Domestic demand is the total sum of final consumption demands by households and government, and investment demand, intermediate consumption demands by activities and transaction services demand. Households' consumption demand is given by a linear expenditure system (LES), derived from maximization of a Stone Geary utility function. The model assumes households maximize utility subject to budget constraints.

The common assumption here is that the economy observed is in general equilibrium. Equilibrium in the goods market is attained through the endogenous interaction of relative prices. In order to clear the factor market, skilled labor and capital are set to be fully employed and activity-specific, implying that sector-specific returns to these factors adjust to guarantee market clearing. Semi-skilled and un-skilled workers have a fixed wage, and their employment levels are determined by the producers' demand for them. Factor land is assumed to have a flexible rent with a certain distortion by sector, which makes it fully employed and mobile across sectors.

The model includes three macroeconomic balances: the current account balance, the government balance, and the savings and investment balance. The current account balance is held constant by assuming flexible exchange rate at a fixed level of foreign savings (fixed in foreign currency). There is an implicit functional relationship between the real exchange rate and the trade balance.

In the government account, the level of government expenditure, equal to consumption and transfers, is fixed in real terms while government revenue is determined by fixed direct and indirect tax rates. Government savings is determined residually as the gap between revenue and expenditure. This closure is chosen since it is assumed that changes in direct and indirect tax rates, as well as in government expenditure, are exogenously determined based on the economic policy.

The macro closure applied for the saving-investment balance is the savings-driven investment closure in which the value of investment is determined by the value of savings, making the simulations possible. Fixed savings rates for all non-governmental institutions and flexible capital formation are specified so that all savings are channeled into investment.

It should be noted that the model designed in this paper can only solve for the relative prices and the real variables of the economy. To achieve this and anchor the absolute price level, a normalization rule has been applied. The consumer price index (CPI) is chosen as the numéraire, so all changes in nominal prices and incomes in simulations are relative to the weighted unit price of households' initial consumption bundle (i.e a fixed CPI). The model is also homogenous of degree zero in prices. In macro terminology, the model displays neutrality of money.

\subsection{Specification of the dynamic model}

In every period the capital stock is updated with the total amount of new investment and depreciation. New capital is distributed among sectors based on each sector's initial share of aggregate capital income. Total labor supply is updated by the population growth rate, i.e. as population grows, the total labor supply increases at the same rate. 
This study originally uses the 2005/06 Ethiopian Development Research Institute (EDRI 2009) national Social Accounting Matrix (SAM) but updated for 2009/10. The SAM is disaggregated into 113 activities (with 77 agricultural activities by agroecological zones, AEZs), 64 commodities, 16 factors (by AEZs except capital), and 13 institutions including 12 households. The SAM also has different taxes, saving-investment, inventory, and rest of the world accounts to show the interaction of different economic agents.

As the current structure of the Ethiopian economy is different from 2005/06 on which the existing SAM is based, the SAM was updated for this particular study to $2009 / 10$ by the following procedure. The dynamic CGE model is used to simulate the growth of the Ethiopian economy based on actual economic developments from 2005/06-2009/10. The resulting solution is a new, balanced SAM for 2009/10. The projected 2009/10 SAM and GDP were then converted to current prices. Actual value added shares of activities and actual aggregate demand components of 2009/10 (from national accounts) were then used to adjust value added by sector in the projected 2009/10 SAM. This resulted in an unbalanced SAM, which was then balanced using a cross entropy program.

\section{Simulation specification and results}

The GTP has set an ambitious investment plan and proposed ways of financing it, though details of the amount of financing from residents and non-residents are not specified. In this study, two options are considered as a means to ensure sufficient finances for investment targets: increased domestic households saving rates and increased foreign savings (through foreign loans, transfers from non-residents, or foreign direct investment).

\subsection{Simulation assumptions}

The analysis consists of five simulations. In the base scenario (BASE), we assume a continuation of the historical growth trends of 2005/06-2009/10 for an additional five years, i.e. through 2014/15. The other four simulations model the medium and high growth scenarios of the GTP under the two different financing options: Medium Growth with Accelerated Domestic Savings (MAD), High Growth with Accelerated Domestic Savings (HAD), Medium Growth with Accelerated Foreign Savings (MAF) and High Growth with Accelerated Foreign Savings (HAF). In all the GTP related simulations, other parameters, apart from the ones used in the specific simulations, are growing at either a fixed trend rate or as indicated in the GTP. Thus, the GTP simulations differ from the BASE one in terms of the assumptions in growth rates of total factor productivity (TFP), the changes in production that cannot be explained in terms of changes in factor supplies ${ }^{4}$, government expenditure, tax rates, and the simulation-specific household savings rates or foreign savings growth rate. For all simulations, annual labor supply is assumed to grow at an average rate of 2.3 percent per year while agricultural land area is set to grow at 2.8 percent per annum based on the recent trend in agricultural land expansion. The tax rate as a percent of GDP is assumed to grow at 3.0 percent in the BASE, and at 7.5 percent in the GTP scenarios. In each simulation, total factor productivity of each activity is adjusted to approximate the GTP overall targets for sectoral (agriculture, industry, and services) growth rates. ${ }^{5}$

\footnotetext{
${ }^{4}$ TFP growth is defined as the growth in real value added adjusted for growth in labor, land, and capital inputs.

${ }^{5}$ The same set of TFP growth rates by activity are used for both the increased household savings rate and increased foreign savings simulations under the medium growth GTP scenarios. Likewise, a common set of (higher) TFP growth rates are used for both the increased household savings rate and increased foreign savings simulations under the high-growth GTP scenarios.
} 
If foreign savings continue growing at the historical trend rate, in order to finance the investment requirement of the GTP, the average household savings rate needs to grow by an average 21.8 percent and 31.1 percent in the medium and high case scenarios, respectively. This means households' marginal propensity to save need to reach 12.5 percent in 2014/15 in the medium case scenario from an average of 5.5 percent in 2014/15 in the base case, to generate sufficient household savings. This is an ambitious target since savings rates in excess of 10 percent are rare. Over the 1990-2008 period, Belgium and Russia achieved average savings rates of 12.5 percent and Italy's savings rate was 13.6 percent. More common are savings rates in the range of 4 to 6 percent, as in the Czech Republic, Slovak Republic, Korea, and the United States (OECD Factbook 2010). Currently, the real interest rate on domestic deposits is negative. To achieve the desired increase in savings, it would require a macroeconomic policy with proper incentives to encourage savings, such as allowing positive real interest rates on bank deposits. Alternatively, if there is no adjustment in households' propensity to save relative to past trends, foreign savings need to increase by 22 percent and 31 percent to meet the investment requirements in the medium and high scenarios of the GTP, respectively (Table 4.1).

Table 4.1. Simulation specific assumptions

\begin{tabular}{|c|c|c|c|c|c|c|}
\hline Simulation & $\begin{array}{c}\text { Average } \\
\text { total factor } \\
\text { productivity } \\
\text { growth } \\
\text { (\% per year) }\end{array}$ & $\begin{array}{l}\text { Investment } \\
\text { growth } \\
\text { (\% per year) }\end{array}$ & $\begin{array}{c}\text { Government } \\
\text { consumption } \\
\text { growth } \\
\text { (\% per year) }\end{array}$ & $\begin{array}{c}\text { Tax as } \% \\
\text { of GDP } \\
\text { growth } \\
(\%)\end{array}$ & $\begin{array}{c}\text { Household } \\
\text { savings rate } \\
\text { growth } \\
\text { (\% per year) }\end{array}$ & $\begin{array}{c}\text { Foreign } \\
\text { savings rate } \\
\text { growth } \\
\text { (\% per year) }\end{array}$ \\
\hline Base & 4.9 & 11.5 & 5.7 & 3.0 & 4.0 & 6.0 \\
\hline MAD & 5.8 & 12.6 & 12.9 & 7.5 & 21.8 & 6.0 \\
\hline HAD & 7.6 & 22.8 & 12.9 & 7.5 & 31.1 & 6.0 \\
\hline MAF & 5.8 & 12.6 & 12.9 & 7.5 & 4.0 & 22.1 \\
\hline HAF & 7.6 & 22.8 & 12.9 & 7.5 & 4.0 & 31.0 \\
\hline
\end{tabular}

Source: MOFED (2010) and simulated parameters.

Notes: MAD: Medium growth with accelerated domestic savings. HAD: High growth with accelerated domestic savings. MAF: Medium growth with accelerated foreign savings. HAF: High growth with accelerated foreign savings.

Over the five years of PASDEP, growth rates in value added (overall GDP) were very high, in spite of relatively modest increases in factor supplies. This implies a very high TFP growth rate-equal to 4.9 percent per year in the model simulation of 2005/06-2009/10 used to update the SAM. This TFP growth rate is in fact very high by historical standards, for example, exceeding the annual TFP growth rates of China (4.1 percent), India (2.8 percent) and Indonesia (1.6 percent) over the 1990 to 2008 period (Table 4.2). ${ }^{6}$ To achieve the GDP growth rates under medium and high growth GTP scenarios requires even higher average TFP growth rates of 5.8 percent and 7.6 percent respectively (Table 4.1). These very high TFP growth rates suggest that it may be very difficult to achieve the plan's growth targets even if levels of financing and investment are forthcoming.

\footnotetext{
${ }^{6}$ OECD data cited in http://www.economist.com/node/14844987.
} 
Table 4.2. Average annual TFP growth rates (\%), 1990-2008

\begin{tabular}{llc}
\hline \multirow{3}{*}{ High } & & TFP growth rate (\%) \\
\cline { 3 - 3 } Medium & India & 4.1 \\
& Singapore & 2.8 \\
& Thailand & 2.3 \\
& South Korea & 1.8 \\
& Indonesia & 1.7 \\
& Japan & 1.6 \\
& United Kingdom & 1.2 \\
& Germany & 1.2 \\
Low & United States & 1.1 \\
& France & 1.1 \\
& South Africa & 1.0 \\
& Mexico & 0.7 \\
& Brazil & 0.5 \\
& Russia & 0.3 \\
\hline
\end{tabular}

Source: OECD data cited in http://www.economist.com/node/14844987

However, to some extent, calculated TFP growth rates for Ethiopia may not be strictly comparable to those of developed countries due to methodological differences in the calculation. In essence, TFP growth is calculated as the difference between growth in value added minus the growth due to changes in labor, capital, and land inputs. In developed countries, growth in labor inputs is calculated using labor input measured in hours or days, and as hours or days worked per worker rise during periods of rapid growth, this increase in labor input is automatically taken into account in TFP calculations. However, for Ethiopia and most developing countries, economy-wide estimates of labor input are only available in person-years with no adjustment for changes in the amount of time a worker works per year. To the extent that Ethiopia's recent rapid economic growth is due to lower underemployment, actual hours and days worked would rise faster than the number of workers, and as a result, true TFP growth will be overstated.

\subsection{Implications of GTP growth scenarios}

By construction of the simulations (setting total factor productivity growth to meet the medium and high growth scenario GDP growth targets), there is essentially no difference in real GDP growth according to the source of financing. Increasing household savings rates, however, results in significantly lower consumption growth-for example, 9.4 percent in the medium growth accelerated domestic savings scenario (MAD) as compared to 11.5 percent in the medium growth accelerated foreign savings (MAF) scenario (Table 4.3). Indeed, private consumption in the former is effectively no different from the baseline case. The other major macro-economic difference between simulations of increased foreign savings versus increased domestic savings rates, is that increased foreign savings leads to a real exchange rate appreciation as the increased financial resources make increased spending on nontradable goods and services (which results in a rise in their price) possible, while the increased spending on tradable goods and services leads to a reduction in exports and an increase in imports. In the medium growth accelerated foreign savings scenario (MAF), the real exchange rate appreciates by 3.5 percent, 2.1 percentage points more than in the medium growth accelerated domestic savings scenario (MAD). Likewise, export growth is considerably slowed: 16.9 percent with accelerated foreign savings (MAF), compared with 22.5 percent with accelerated domestic savings (MAD). 
Table 4.3. Simulation results: macro-economic variables

\begin{tabular}{|c|c|c|c|c|c|c|}
\hline & \multirow{3}{*}{ INITIAL } & \multicolumn{5}{|c|}{ Average Annual Growth Rate (\%) } \\
\hline & & \multirow[t]{2}{*}{ BASE } & \multicolumn{2}{|c|}{$\begin{array}{c}\text { Increased } \\
\text { Domestic Savings }\end{array}$} & \multicolumn{2}{|c|}{$\begin{array}{c}\text { Increased } \\
\text { Foreign Savings }\end{array}$} \\
\hline & & & MAD & HAD & MAF & HAF \\
\hline GDP & 355.0 & 10.6 & 11.2 & 14.9 & 11.2 & 14.9 \\
\hline Investment & 85.5 & 11.5 & 12.6 & 22.8 & 12.6 & 22.8 \\
\hline Government & 31.8 & 5.7 & 12.9 & 12.9 & 12.9 & 12.9 \\
\hline Private Consumption & 338.6 & 9.6 & 9.4 & 10.6 & 11.5 & 14.2 \\
\hline Exports & 52.1 & 20.8 & 22.5 & 28.5 & 16.9 & 19.9 \\
\hline Imports & 126.5 & 12.7 & 13.6 & 17.1 & 15.5 & 20.1 \\
\hline Real Exchange Rate & 90.9 & 0.1 & -1.4 & 0.9 & -3.5 & -3.1 \\
\hline Foreign Savings & 35.7 & 6.0 & 6.0 & 6.0 & 22.1 & 31.0 \\
\hline Government Savings & 35.5 & 9.1 & -11.5 & 11.0 & -14.0 & 7.1 \\
\hline Household Income & 360.4 & 10.3 & 11.5 & 13.7 & 12.0 & 14.4 \\
\hline Rural & 325.8 & 10.4 & 11.2 & 13.5 & 11.8 & 14.4 \\
\hline Urban & 34.6 & 9.0 & 14.1 & 15.4 & 13.8 & 15.0 \\
\hline
\end{tabular}

Source: Model simulations.

Notes: MAD: Medium growth with accelerated domestic savings. HAD: High growth with accelerated domestic savings. MAF: Medium growth with accelerated foreign savings. HAF: High growth with accelerated foreign savings.

Government savings are higher in the high growth scenario than in the medium growth scenario under both financing options. As expected, given a similar growth in government spending in both GTP scenarios, with slower productivity growth, income growth and government revenue growth are less and thus government savings fall over time; with faster productivity growth, however, tax revenues rise and government savings increase. Despite higher government savings in the high growth scenarios, the large investment demand still requires additional financing from household or foreign savings.

Returns for all the factors increase significantly in all the scenarios, with generally higher returns when the investment is financed through foreign savings than through increased household savings (Table 4.4), since in the former scenarios the rise in the output price of non-tradable goods generally increases the incomes of labor, land, and capital in these sectors. In the base case, which broadly replicates the economic growth path achieved under PASDEP with relatively high agricultural growth, the average annual growth rates of income of agricultural labor (10.4 percent), land (12.3 percent), and livestock (14.3 percent) rise faster than incomes of skilled labor (9.2 percent) and capital (9.3 percent). Under the GTP scenarios involving greater investment and TFP growth in non-agricultural sectors, however, incomes of skilled labor and capital rise faster than agricultural or rural sectors (except livestock). 
Table 4.4. Simulation results: factor incomes

\begin{tabular}{|c|c|c|c|c|c|c|c|}
\hline \multirow{3}{*}{ Factors } & \multirow{2}{*}{\multicolumn{2}{|c|}{ Initial }} & \multicolumn{5}{|c|}{ Average Annual Growth Rate (\%) } \\
\hline & & & \multirow[t]{2}{*}{ BASE } & \multicolumn{2}{|c|}{$\begin{array}{c}\text { Increased } \\
\text { Domestic Savings }\end{array}$} & \multicolumn{2}{|c|}{$\begin{array}{c}\text { Increased } \\
\text { Foreign Savings } \\
\end{array}$} \\
\hline & Billion Birr & Share & & MAD & HAD & MAF & HAF \\
\hline Labor -Skilled* & 77.5 & $21.8 \%$ & 9.2 & 14.1 & 16.9 & 13.2 & 15.3 \\
\hline Labor-unskilled & 39.4 & $11.1 \%$ & 10.6 & 9.9 & 12.0 & 11.3 & 14.0 \\
\hline Labor & 57.1 & $16.1 \%$ & 10.4 & 9.1 & 10.3 & 10.6 & 12.8 \\
\hline Capital & 110.3 & $31.1 \%$ & 9.3 & 11.7 & 14.6 & 11.3 & 14.0 \\
\hline Land & 39.8 & $11.2 \%$ & 12.3 & 10.5 & 12.4 & 12.4 & 15.3 \\
\hline Livestock & 30.9 & $8.7 \%$ & 14.3 & 12.9 & 13.2 & 15.4 & 17.7 \\
\hline Total & 355.0 & $100.0 \%$ & 10.4 & 11.6 & 13.9 & 12.1 & 14.6 \\
\hline
\end{tabular}

Source: Model simulations.

Notes: MAD: Medium growth with accelerated domestic savings. HAD: High growth with accelerated domestic savings. MAF:

Medium growth with accelerated foreign savings. HAF: High growth with accelerated foreign savings.

* Includes semi-skilled labor

Overall, the huge investments and the resulting faster GDP growth under the GTP result in substantial increases in real incomes of both poor and non-poor households. Continuation of the investments and productivity growth patterns as under PASDEP from 2004/05 to 2009/10 (BASE) would increase average real incomes by 10.4 percent per year. Average growth in household incomes rises from 11.6 (with increased domestic savings) to 12.1 percent per year (with increased foreign savings) under the GTP medium growth scenarios (Table 4.5). Overall, higher household income growth is achieved with increased foreign saving inflows (as compared to increased domestic savings) because these inflows increase total resources in the economy. It should be noted that household consumption also rises more with increased foreign savings than domestic savings. However, if the foreign savings are in the form of loans that are to be repaid, then the consumption growth will be temporary. Therefore, household income is chosen as the preferred indicator for the more permanent gains from increased foreign savings.

Table 4.5. Simulation results: household incomes

\begin{tabular}{|c|c|c|c|c|c|c|}
\hline \multirow{3}{*}{ Household group } & \multirow{3}{*}{$\begin{array}{c}\text { INITIAL } \\
\text { Billion Birr }\end{array}$} & \multicolumn{5}{|c|}{ Average Annual Growth Rate (\%) } \\
\hline & & \multirow[t]{2}{*}{ BASE } & \multicolumn{2}{|c|}{$\begin{array}{c}\text { Increased } \\
\text { Domestic Savings }\end{array}$} & \multicolumn{2}{|c|}{$\begin{array}{c}\text { Increased Foreign } \\
\text { Savings }\end{array}$} \\
\hline & & & MAD & HAD & MAF & HAF \\
\hline Rural & 325.8 & 10.4 & 11.2 & 13.5 & 11.8 & 14.4 \\
\hline Rural poor & 74.6 & 10.6 & 10.0 & 12.1 & 11.2 & 13.8 \\
\hline Rural non-poor & 251.2 & 10.3 & 11.5 & 13.9 & 11.9 & 14.5 \\
\hline Urban & 34.6 & 9.0 & 14.1 & 15.4 & 13.8 & 15.0 \\
\hline Urban poor & 3.7 & 9.0 & 11.6 & 14.2 & 11.6 & 13.9 \\
\hline Urban non-poor & 30.9 & 9.0 & 14.4 & 15.5 & 14.0 & 15.1 \\
\hline
\end{tabular}

Source: Model simulations.

Notes: MAD: Medium growth with accelerated domestic savings. HAD: High growth with accelerated domestic savings. MAF: Medium growth with accelerated foreign savings. HAF: High growth with accelerated foreign savings.

Note that if the economy continues with its performance as in the PASDEP period, income of rural households would increase faster than that of urban households (Figure 4.1). In particular, in this scenario (BASE), income growth is lowest for both the urban poor and nonpoor and highest for the rural poor. Under the GTP, however, incomes of the non-poor increase faster than incomes of the poor under both financing options. This result is largely because of the high returns to capital and skilled labor under the GTP that accrue mainly to non-poor households. 
Figure 4.1. Simulation results: household incomes

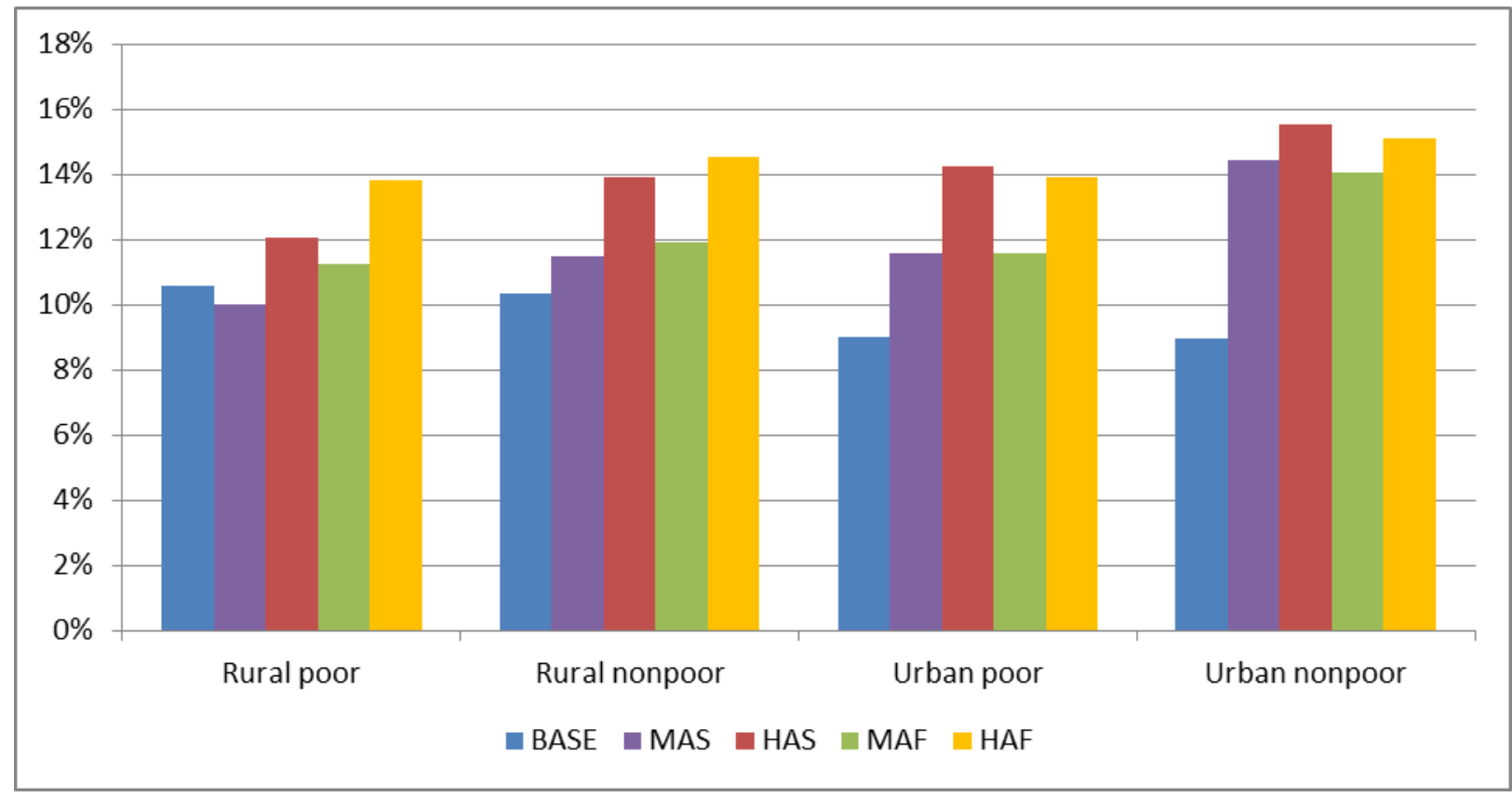

Source: Model simulations.

Notes: MAD: Medium growth with accelerated domestic savings. HAD: High growth with accelerated domestic savings. MAF:

Medium growth with accelerated foreign savings. HAF: High growth with accelerated foreign savings.

Comparing across financing options, rural domestic incomes rise less in the increased household savings scenario since household spending on agricultural products is reduced (relative to the increased foreign savings scenarios). On the other hand, urban household incomes rise less in the increased foreign savings scenario than in the increased household savings scenario because the real exchange rate appreciation in the former scenario makes domestic production of import substitute industrial products less profitable, thereby reducing earnings of skilled labor and capital.

Household total expenditure increases significantly in all household groups, in all simulations and financing alternatives (Table 4.6). Total expenditures of the urban non-poor grows the fastest in the medium growth scenario of the GTP, as a result of faster growth in the industry sector compared to the other sectors. In the high growth scenario of the GTP on the other hand, expenditure of the rural non-poor grows more or less the fastest due to faster growth in agriculture. The rate of increase in household consumption significantly differs between the financing options. As expected, the rate of increase in total household expenditure under the domestic saving option is lower in all household groups than under the foreign financing alternative, as households are supposed to save more, at the expense of consumption. The poor are spending even less than they would be able to with the continuation of the economic performance during the PASDEP. 
Table 4.6. Simulation results: household expenditures

\begin{tabular}{|c|c|c|c|c|c|c|}
\hline \multirow{3}{*}{ Household group } & \multirow{3}{*}{$\begin{array}{c}\text { Initial } \\
\text { Billion Birr }\end{array}$} & \multicolumn{5}{|c|}{ Average Annual Growth Rate (\%) } \\
\hline & & \multirow[t]{2}{*}{ BASE } & \multicolumn{2}{|c|}{$\begin{array}{c}\text { Increased } \\
\text { Domestic Savings }\end{array}$} & \multicolumn{2}{|c|}{$\begin{array}{c}\text { Increased Foreigr } \\
\text { Savings }\end{array}$} \\
\hline & & & MAD & HAD & MAF & HAF \\
\hline Rural & 308.1 & 10.1 & 9.2 & 10.2 & 11.4 & 14.0 \\
\hline Rural poor & 70.1 & 10.3 & 7.6 & 7.7 & 10.9 & 13.5 \\
\hline Rural non-poor & 238.0 & 10.1 & 9.2 & 10.2 & 11.5 & 14.2 \\
\hline Urban & 30.4 & 8.5 & 11.1 & 10.6 & 12.6 & 13.8 \\
\hline Urban poor & 3.4 & 8.9 & 8.4 & 8.0 & 11.3 & 13.5 \\
\hline Urban non-poor & 27.0 & 8.4 & 11.4 & 10.9 & 12.8 & 13.8 \\
\hline
\end{tabular}

Source: Model simulations.

Notes: MAD: Medium growth with accelerated domestic savings. HAD: High growth with accelerated domestic savings. MAF:

Medium growth with accelerated foreign savings. HAF: High growth with accelerated foreign savings.

Financing the investment through increased foreign savings allows each of the domestic household groups to increase their consumption level at a higher rate. This may seem to suggest that increasing foreign savings is a better alternative but, in reality, it simply reflects that the analysis that we are conducting ignores the accumulation of assets by the actors in the model: if foreign savings consist of foreign direct investment or foreign borrowing, they will tend to reduce the share of output that is available to Ethiopian residents.

The analysis shows that regardless of the financing strategy, there will be high income growth for poor and rich alike under the GTP. Urban households will enjoy larger income increases than rural households. Further, unskilled labor and agricultural labor will not fare any better under the medium growth scenarios than under the baseline without the GTP (except for a slight improvement for unskilled labor under the MAF scenario). Consequently, the rural poor will have lower average income growth rates under MAD (10.0 percent) than under the baseline (10.6 percent).

\section{Summary and conclusions}

The Growth and Transformation Plan has set higher growth and investment targets than those of any of Ethiopia's earlier national plans and its implementation requires faster growth in total factor productivity and mobilization of huge savings both from domestic and foreign sources. The 4.9 percent annual TFP growth needed to reproduce the high GDP growth under PASDEP (2005/06 to 2009/10) or to continue this growth into the future is very high as compared to those that other fast-growing economies such as India, China or Indonesia have been able to achieve. Achieving the GTP target GDP growth rates requires even higher TFP growth: by 5.8 and 7.6 percent per year in the medium and high growth GTP scenarios, respectively. To some extent, some of this productivity growth could be achieved through reduced underemployment. Nonetheless, it is not clear how these high TFP growth rates can be achieved, suggesting that the projected GDP growth outcomes are very optimistic.

Meeting the financing requirements for the GTP will also be challenging given the large amount that needs to be mobilized, as compared to the low historical savings in Ethiopia. In the model simulations where the additional finance is mobilized from domestic sources, households' savings rates increase from an average of 5.5 percent of total household income in 2014/15 in the base case to 12.5 percent of total household income in 2014/15 in the increased household savings/medium case scenario. Achieving this high rate of 
domestic savings would also require changes in macroeconomic policy, such as increases in tax rates or increases in interest rates to encourage private savings. If the additional finance is mobilized through increased foreign borrowing/transfers, foreign savings would need to increase from 47.7 billion birr in 2014/15 of the base case to 96.8 billion birr in 2014/15 of the medium case in real terms (i.e. from 7.5 percent to 14.8 percent of GDP).

Results from the simulations on financing options also show that private consumption is lower when the GTP is financed through increases in household savings as compared to financing through increased foreign savings. However, although considerable increment in exports and imports were observed in both of the GTP related simulations, growth in exports is lower under the increased foreign savings scenarios due to an appreciation of the real exchange rate relative to the increased household savings scenarios.

Regardless of the financing strategy, the high total factor productivity and GDP growth rates under the GTP imply high average income growth for both poor and rich households, in both rural and urban areas. Because the GTP involves a greater concentration of investment in non-agricultural sectors than did PASDEP, growth of incomes of urban households is higher in the GTP than under PASDEP. Conversely, income growth of the rural poor is slightly lower under the medium growth scenario with domestic savings (10.0 percent) than under a continuation of PASDEP growth and investment (10.6 percent).

It should be noted that the results presented here do not take into consideration possible additional migration of labor from rural to urban areas arising from faster growing urban incomes, or possible positive agglomeration effects on total factor productivity from growth in urban centers. Including these factors would raise the incomes of urban households relative to rural households and raise total GDP, but would not reverse the general result that investments in agriculture reduce poverty faster than investments in non-agriculture (Dorosh and Thurlow 2011).

Thus, this analysis shows that if the GTP investment and sectoral growth targets are achieved, real incomes of the poor in Ethiopia would rise substantially. The base simulations indicate that real incomes of the poor rose under PASDEP from 2005/06 to 2010/11 and that these incomes would also rise if PASDEP growth continued. Under GTP, this real income growth would be accelerated, provided there is sufficient foreign savings or mobilization of domestic savings to achieve the targets. Nonetheless, the simulations also suggest that agricultural growth will still be crucial for raising incomes of Ethiopia's rural poor. Thus, investments that raise agricultural productivity will need to continue in order to ensure that the rural poor share in the substantial projected benefits that would result from achieving the high economic growth targets of the GTP. 


\section{Appendix}

\section{Appendix A.1. Specification of the CGE and micro-simulation model adapted from Dorosh and Thurlow (2009)}

A computable general equilibrium (CGE) model was developed to assess sector-specific growth options. The model is calibrated to the Economic Development Research Institute's 2005 social accounting matrix (SAM) that provides information on demand and production for 69 detailed sectors. The model further disaggregates agricultural activities across agroecological regions using data from the 2005 agricultural sample survey. Based on the SAM, the production technologies across all sectors are calibrated to their current situation, including each sector's use of primary inputs, such as land, labor, and capital, and intermediate inputs. To capture existing differences in labor markets, the model classifies employed labor into different sub-categories, including skilled, semi-skilled, and unskilled workers based on occupational categories. Information on employment and wages by sector and region is taken from the $2005 / 06$ household income and expenditure survey.

Most workers in the model can migrate between regions and sectors. These workers are disaggregated according to occupational categories (i.e. administrators, professional, skilled, and unskilled). Agricultural family labor is region-specific but mobile across agricultural subsectors. Both agricultural and nonagricultural capital investments move freely across regions and within the broad non-agriculture sector. The accumulation of capital is through investment financed by domestic savings and foreign inflows. Increased capital is allocated across sectors and regions according to their relative profitability. Once invested, capital becomes sector-specific and can only by adjusted through exogenously-determined depreciation and the attraction of new investments. Incomes from employment accrue to households according to employment and wage data from the household survey. This detailed specification of production and factor markets in the model allows it to capture the changing scale and technology of production across sectors and sub-national regions, and therefore, how changes in the economic structure of growth influence its distribution of incomes.

The model captures production linkages by explicitly defining a set of nested constant elasticity of substitution (CES) production functions allowing producers to generate demand for both factors and intermediates. The CGE model also captures forward and backward production linkages between sectors. Import competition and export opportunities are modeled by allowing producers and consumers to shift between domestic and foreign markets depending on changes in the relative prices of imports, exports, and domestic goods. More specifically, the decision of producers to supply domestic or foreign markets is governed by a constant elasticity of transformation (CET) function, while substitution possibilities exist between imports and domestically supplied goods under a CES Armington specification. In this way the model captures how import-competition and the changing export opportunities of agriculture and industry can strengthen or weaken the linkages between growth and poverty.

Incomes from production, trade, and employment accrue to different households according to employment and wage data from the household survey. As with production, households are defined at the regional level, and within each region, by rural and urban areas and poor/non-poor categories. Poverty is defined as the bottom two per capita expenditure quintiles. Income and expenditure patterns vary considerably across these household groups. These differences are important for distributional change, since incomes generated by agricultural growth accrue to different households depending on their location and factor endowments. Each representative household in the model is an aggregation of a group of 
households in the household survey. Households in the model receive income through the employment of their factors in both agricultural and nonagricultural production, and then pay taxes, save, and make transfers to other households. The disposable income of a representative household is allocated to commodity consumption derived from a StoneGeary utility function (i.e. a linear expenditure system of demand).

The model makes a number of assumptions about how the economy maintains macroeconomic balance. These closure rules concern the foreign or current account, the government or public sector account, and the savings-investment account. For the current account, a flexible exchange rate maintains a fixed level of foreign savings. This assumption implies that the country cannot simply increase foreign debt but has to generate export earnings in order to pay for imported goods and services. While this assumption realistically limits the degree of import competition in the domestic market, it also underlines the importance of the agricultural and industrial export sectors. For the government account, tax rates and real consumption expenditure are exogenously determined, leaving the fiscal deficit to adjust to ensure that public expenditures equal receipts. For the savings-investment account, real investment adjusts to changes in savings (i.e. savings-driven investment). These two assumptions allow the models to capture the effects of growth on the level of public investment and the crowding-out effect from changes in government revenues.

Finally, the CGE model is recursive dynamic, which means that some exogenous stock variables in the models are updated each period based on inter-temporal behavior and results from previous periods. The model is run over the period 2005-2015, with each equilibrium period representing a single year. The model also exogenously captures demographic and technological change, including population, labor supply, human capital, and factor-specific productivity. Capital accumulation occurs through endogenous linkages with previous-period investment. Although the allocation of newly invested capital is influenced by each sector's initial share of gross operating surplus, the final allocation depends on depreciation and sector profit-rate differentials. Sectors with above-average returns in the previous period receive a larger share of the new capital stock in the current period.

In summary, the CGE model incorporates distributional change by (1) disaggregating growth across sub-national regions and sectors; (2) capturing income-effects through factor markets and price-effects through commodity markets; and (3) translating these two effects onto each household in the survey according to its unique factor endowment and income and expenditure patterns. The structure of the growth-poverty relationship is therefore defined explicitly ex ante based on observed country-specific structures and behavior. This allows the model to capture the poverty and distributional changes associated with agricultural growth. 
Table A.2. CGE model sets, parameters, and variables

\begin{tabular}{|c|c|c|c|}
\hline Symbol & Explanation & Symbol & Explanation \\
\hline \multicolumn{4}{|l|}{ Sets } \\
\hline$a \in A$ & Activities & $c \in C M N(\subset C)$ & Commodities not in $\mathrm{CM}$ \\
\hline$a \in A L E O(\subset A)$ & $\begin{array}{l}\text { Activities with a Leontief function } \\
\text { at the top of the technology nest }\end{array}$ & $c \in C T(\subset C)$ & $\begin{array}{l}\text { Transaction service } \\
\text { commodities }\end{array}$ \\
\hline$c \in C$ & Commodities & $c \in C X(\subset C)$ & $\begin{array}{l}\text { Commodities with } \\
\text { domestic production }\end{array}$ \\
\hline$c \in C D(\subset C)$ & $\begin{array}{l}\text { Commodities with domestic sales } \\
\text { of domestic output }\end{array}$ & $f \in F$ & Factors \\
\hline$c \in C D N(\subset C)$ & Commodities not in $C D$ & $i \in I N S$ & $\begin{array}{l}\text { Institutions (domestic and } \\
\text { rest of world) }\end{array}$ \\
\hline$c \in C E(\subset C)$ & Exported commodities & $i \in I N S D(\subset I N S)$ & Domestic institutions \\
\hline$c \in C E N(\subset C)$ & Commodities not in $C E$ & $i \in I N S D N G(\subset I N S D)$ & $\begin{array}{l}\text { Domestic non-government } \\
\text { institutions }\end{array}$ \\
\hline$c \in C M(\subset C)$ & Aggregate imported commodities & $h \in H(\subset I N S D N G)$ & Households \\
\hline \multicolumn{4}{|l|}{ Parameters } \\
\hline$c w t s_{c}$ & Weight of commodity $\mathrm{c}$ in the CPI & $q d s t_{c}$ & Quantity of stock change \\
\hline$d w t s_{c}$ & $\begin{array}{l}\text { Weight of commodity } c \text { in the } \\
\text { producer price index }\end{array}$ & $\overline{q g}_{c}$ & $\begin{array}{l}\text { Base-year quantity of } \\
\text { government demand }\end{array}$ \\
\hline$i c a_{c a}$ & $\begin{array}{l}\text { Quantity of c as intermediate } \\
\text { input per unit of activity a }\end{array}$ & $\overline{\operatorname{qinv}}_{c}$ & $\begin{array}{l}\text { Base-year quantity of } \\
\text { private investment } \\
\text { demand }\end{array}$ \\
\hline$i c d_{c c^{\prime}}$ & $\begin{array}{l}\text { Quantity of commodity c as trade } \\
\text { input per unit of c' produced and } \\
\text { sold domestically }\end{array}$ & shif $_{\text {if }}$ & $\begin{array}{l}\text { Share for domestic } \\
\text { institution i in income of } \\
\text { factor } f\end{array}$ \\
\hline ice $_{c c^{\prime}}$ & $\begin{array}{l}\text { Quantity of commodity c as trade } \\
\text { input per exported unit of c' }\end{array}$ & $s h i i_{i i^{\prime}}$ & $\begin{array}{l}\text { Share of net income of i' } \\
\text { to i (i' } \in \text { INSDNG'; i } \in \\
\text { INSDNG) }\end{array}$ \\
\hline$i c m_{c c^{\prime}}$ & $\begin{array}{l}\text { Quantity of commodity c as trade } \\
\text { input per imported unit of c' } \\
\text { Quantity of aqareaate }\end{array}$ & $t a_{a}$ & Tax rate for activity a \\
\hline inta $_{a}$ & $\begin{array}{l}\text { intermediate input per activity } \\
\text { unit }\end{array}$ & $\overline{\operatorname{tins}}_{i}$ & $\begin{array}{l}\text { Exogenous direct tax rate } \\
\text { for domestic institution } i\end{array}$ \\
\hline iva $_{a}$ & $\begin{array}{l}\text { Quantity of aggregate } \\
\text { intermediate input per activity } \\
\text { unit }\end{array}$ & $\operatorname{tins} O 1_{i}$ & $\begin{array}{l}0-1 \text { parameter with } 1 \text { for } \\
\text { institutions with potentially } \\
\text { flexed direct tax rates }\end{array}$ \\
\hline$m p s_{i}$ & $\begin{array}{l}\text { Base savings rate for domestic } \\
\text { institution } \mathrm{i} \\
0-1 \text { parameter with } 1 \text { for }\end{array}$ & $t m_{c}$ & Import tariff rate \\
\hline $\operatorname{mps} 01_{i}$ & $\begin{array}{l}\text { institutions with potentially flexed } \\
\text { direct tax rates }\end{array}$ & $t q_{c}$ & Rate of sales tax \\
\hline$p w e_{c}$ & Export price (foreign currency) & trnsfr $r_{i f}$ & $\begin{array}{l}\text { Transfer from factor } \mathrm{f} \text { to } \\
\text { institution } \mathrm{i}\end{array}$ \\
\hline$p w m_{c}$ & Import price (foreign currency) & & \\
\hline
\end{tabular}


Table A.2. continued. CGE model sets, parameters, and variables

\begin{tabular}{|c|c|c|c|}
\hline Symbol & Explanation & Symbol & Explanation \\
\hline \multicolumn{4}{|c|}{ Greek Symbols } \\
\hline$\alpha_{a}^{a}$ & $\begin{array}{l}\text { Efficiency parameter in the CES activity } \\
\text { function }\end{array}$ & $\delta_{c r}^{t}$ & CET function share parameter \\
\hline$\alpha_{a}^{v a}$ & $\begin{array}{l}\text { Efficiency parameter in the CES value- } \\
\text { added function }\end{array}$ & $\delta_{f a}^{v a}$ & $\begin{array}{l}\text { CES value-added function share } \\
\text { parameter for factor } f \text { in activity } a\end{array}$ \\
\hline$\alpha_{c}^{a c}$ & $\begin{array}{l}\text { Shift parameter for domestic } \\
\text { commodity aggregation function }\end{array}$ & $\gamma_{c h}^{m}$ & $\begin{array}{l}\text { Subsistence consumption of marketed } \\
\text { commodity } \mathrm{c} \text { for household } \mathrm{h}\end{array}$ \\
\hline$\alpha_{c}^{q}$ & Armington function shift parameter & $\theta_{a c}$ & Yield of output c per unit of activity a \\
\hline$\alpha_{c}^{t}$ & CET function shift parameter & $\rho_{a}^{a}$ & CES production function exponent \\
\hline$\beta^{a}$ & Capital sectoral mobility factor & $\rho_{a}^{v a}$ & CES value-added function exponent \\
\hline$\beta_{c h}^{m}$ & $\begin{array}{l}\text { Marginal share of consumption } \\
\text { spending on marketed commodity c for } \\
\text { household } \mathrm{h}\end{array}$ & $\rho_{c}^{a c}$ & $\begin{array}{l}\text { Domestic commodity aggregation } \\
\text { function exponent }\end{array}$ \\
\hline$\delta_{a}^{a}$ & CES activity function share parameter & $\rho_{c}^{q}$ & Armington function exponent \\
\hline$\delta_{a c}^{a c}$ & $\begin{array}{l}\text { Share parameter for domestic } \\
\text { commodity aggregation function }\end{array}$ & $\rho_{c}^{t}$ & CET function exponent \\
\hline$\delta_{c r}^{q}$ & Armington function share parameter & $\eta_{\text {fat }}^{a}$ & Sector share of new capital \\
\hline$v_{f}$ & Capital depreciation rate & $Q F_{f a}$ & Quantity demanded of factor $f$ \\
\hline \multicolumn{4}{|c|}{ Exogenous Variables } \\
\hline$\overline{C P I}$ & Consumer price index & $\overline{M P S A D J}$ & $\begin{array}{l}\text { Savings rate scaling factor (= } 0 \text { for } \\
\text { base) }\end{array}$ \\
\hline$\overline{D T I N S}$ & $\begin{array}{l}\text { Change in domestic institution tax } \\
\text { share (= } 0 \text { for base; exogenous } \\
\text { variable) }\end{array}$ & $\overline{Q F S}_{f}$ & Quantity supplied of factor \\
\hline$\overline{F S A V}$ & Foreign savings (FCU) & $\overline{T I N S A D J}$ & $\begin{array}{l}\text { Direct tax scaling factor (= } 0 \text { for base; } \\
\text { exogenous variable) }\end{array}$ \\
\hline$\overline{G A D J}$ & Government consumption adjustment & $\overline{W F D I S T}_{f a}$ & $\begin{array}{l}\text { Wage distortion factor for factor } \mathrm{f} \text { in } \\
\text { activity a }\end{array}$ \\
\hline$\overline{I A D J}$ & Investment adjustment factor & & \\
\hline \multicolumn{4}{|c|}{ Endogenous Variables } \\
\hline$A W F_{f t}^{a}$ & $\begin{array}{l}\text { Average capital rental rate in time } \\
\text { period } t\end{array}$ & $Q G_{c}$ & $\begin{array}{l}\text { Government consumption demand for } \\
\text { commodity }\end{array}$ \\
\hline$D M P S$ & $\begin{array}{l}\text { Change in domestic institution savings } \\
\text { rates ( }=0 \text { for base; exogenous } \\
\text { variable) }\end{array}$ & $Q H_{c h}$ & $\begin{array}{l}\text { Quantity consumed of commodity c by } \\
\text { household } h\end{array}$ \\
\hline$D P I$ & $\begin{array}{l}\text { Producer price index for domestically } \\
\text { marketed output }\end{array}$ & $Q H A_{a c h}$ & $\begin{array}{l}\text { Quantity of household home } \\
\text { consumption of commodity c from } \\
\text { activity a for household h }\end{array}$ \\
\hline$E G$ & Government expenditures & $Q_{I N T A}$ & $\begin{array}{l}\text { Quantity of aggregate intermediate } \\
\text { input }\end{array}$ \\
\hline$E H_{h}$ & Consumption spending for household & $Q I N T_{c a}$ & $\begin{array}{l}\text { Quantity of commodity c as } \\
\text { intermediate input to activity a }\end{array}$ \\
\hline$E X R$ & Exchange rate (LCU per unit of FCU) & $Q I N V_{c}$ & $\begin{array}{l}\text { Quantity of investment demand for } \\
\text { commodity }\end{array}$ \\
\hline$G S A V$ & Government savings & $Q M_{c r}$ & Quantity of imports of commodity c \\
\hline
\end{tabular}


Table A.2. continued. CGE model sets, parameters, and variables

\begin{tabular}{|c|c|c|c|}
\hline \multicolumn{2}{|c|}{$\begin{array}{ll}\text { Symbol } & \text { Explanation } \\
\text { Endogenous Variables - Continued }\end{array}$} & Symbol & Explanation \\
\hline \multicolumn{4}{|c|}{ Endogenous Variables - Continued } \\
\hline $\operatorname{MPS}_{i}$ & $\begin{array}{l}\text { Marginal propensity to save for } \\
\text { domestic non-government } \\
\text { institution (exogenous variable) }\end{array}$ & $Q Q_{c}$ & $\begin{array}{l}\text { Quantity of goods supplied to } \\
\text { domestic market (composite } \\
\text { supply) }\end{array}$ \\
\hline$P A_{a}$ & $\begin{array}{l}\text { Activity price (unit gross } \\
\text { revenue) }\end{array}$ & $Q T_{c}$ & $\begin{array}{l}\text { Quantity of commodity } \\
\text { demanded as trade input }\end{array}$ \\
\hline$P D D_{c}$ & $\begin{array}{l}\text { Demand price for commodity } \\
\text { produced and sold domestically }\end{array}$ & $Q V A_{a}$ & $\begin{array}{l}\text { Quantity of (aggregate) value- } \\
\text { added }\end{array}$ \\
\hline$P D S_{c}$ & $\begin{array}{l}\text { Supply price for commodity } \\
\text { produced and sold domestically }\end{array}$ & $Q X_{c}$ & $\begin{array}{l}\text { Aggregated quantity of } \\
\text { domestic output of commodity }\end{array}$ \\
\hline$P E_{c r}$ & $\begin{array}{l}\text { Export price (domestic } \\
\text { currency) }\end{array}$ & $Q X A C_{a c}$ & $\begin{array}{l}\text { Quantity of output of } \\
\text { commodity c from activity a }\end{array}$ \\
\hline PINTA $_{a}$ & $\begin{array}{l}\text { Aggregate intermediate input } \\
\text { price for activity a }\end{array}$ & $R W F_{f}$ & Real average factor price \\
\hline$P K_{f t}$ & $\begin{array}{l}\text { Unit price of capital in time } \\
\text { period } t\end{array}$ & $T A B S$ & Total nominal absorption \\
\hline$P M_{c r}$ & $\begin{array}{l}\text { Import price (domestic } \\
\text { currency) }\end{array}$ & TINS $_{i}$ & $\begin{array}{l}\text { Direct tax rate for institution i (i } \\
\in \text { INSDNG) }\end{array}$ \\
\hline$P Q_{c}$ & Composite commodity price & $T R I I_{i i^{\prime}}$ & $\begin{array}{l}\text { Transfers from institution i' to i } \\
\text { (both in the set INSDNG) }\end{array}$ \\
\hline$P V A_{a}$ & $\begin{array}{l}\text { Value-added price (factor } \\
\text { income per unit of activity) }\end{array}$ & $W F_{f}$ & Average price of factor \\
\hline$P X_{c}$ & $\begin{array}{l}\text { Aggregate producer price for } \\
\text { commodity }\end{array}$ & $Y F_{f}$ & Income of factor $f$ \\
\hline$P X A C_{a c}$ & $\begin{array}{l}\text { Producer price of commodity } \mathrm{C} \\
\text { for activity a }\end{array}$ & $Y G$ & Government revenue \\
\hline$Q A_{a}$ & Quantity (level) of activity & $Y I_{i}$ & $\begin{array}{l}\text { Income of domestic non- } \\
\text { government institution }\end{array}$ \\
\hline$Q D_{c}$ & $\begin{array}{l}\text { Quantity sold domestically of } \\
\text { domestic output }\end{array}$ & $Y I F_{i f}$ & $\begin{array}{l}\text { Income to domestic institution } \mathrm{i} \\
\text { from factor } \mathrm{f}\end{array}$ \\
\hline$Q E_{c r}$ & Quantity of exports & $\Delta K_{f a t}^{a}$ & $\begin{array}{l}\text { Quantity of new capital by } \\
\text { activity a for time period t }\end{array}$ \\
\hline
\end{tabular}


Table A.3. CGE model equations

Production and Price Equations

QINT $_{c a}=i c a_{c a} \cdot$ QINTA $_{a}$

$P I N T A_{a}=\sum_{c \in C} P Q_{c} \cdot i c a_{c a}$

$Q V A_{a}=\alpha_{a}^{v a} \cdot\left(\sum_{f \in F} \delta_{f a}^{v a} \cdot\left(\alpha_{f a}^{v a f} \cdot Q F_{f a}\right)^{-\rho_{a}^{v a}}\right)^{-\frac{1}{\rho_{a}^{v a}}}$

$W_{f} \cdot \overline{W F D I S T}_{f a}=P V A_{a} \cdot Q V A_{a} \cdot\left(\sum_{f \in F^{\prime}} \delta_{f a}^{v a} \cdot\left(\alpha_{f a}^{v a f} \cdot Q F_{f a}\right)^{-\rho_{a}^{v a}}\right)^{-1} \cdot \delta_{f a}^{v a} \cdot\left(\alpha_{f a}^{v a f} \cdot Q F_{f a}\right)^{-\rho_{a}^{v a}-1}$

$Q F_{f a}=\alpha_{f a}^{v a n} \cdot\left(\sum_{f^{\prime} \in F} \delta_{f f^{\prime} a}^{v a n} \cdot Q F_{f^{\prime} a}^{-\rho_{f a}^{v a n}}\right)^{-\frac{1}{\rho_{f a}^{v a n}}}$

$W_{f^{\prime}} \cdot W F D I S T_{f^{\prime} a}=W_{f} \cdot W F D I S T T_{f a} \cdot Q F_{f a} \cdot\left(\sum_{f^{\prime \prime} \in F} \delta_{f f^{\prime \prime} a}^{v a n} \cdot Q F_{f^{\prime \prime} a}^{-\rho_{f a}^{v a n}}\right)^{-1} \cdot \delta_{f^{\prime} a}^{v a n} \cdot Q F_{f^{\prime} a}^{-\rho_{f a}^{v a n}-1}$

$Q V A_{a}=i v a_{a} \cdot Q A_{a}$

$\operatorname{QINTA}_{a}=\operatorname{inta}_{a} \cdot Q A_{a}$

$P A_{a} \cdot\left(1-t a_{a}\right) \cdot Q A_{a}=P V A_{a} \cdot Q V A_{a}+P I N T A_{a} \cdot Q_{I N T A}$

$Q X A C_{a c}=\theta_{a c} \cdot Q A_{a}$

$P A_{a}=\sum_{c \in C} P X A C_{a c} \cdot \theta_{a c}$

$Q X_{c}=\alpha_{c}^{a c} \cdot\left(\sum_{a \in A} \delta_{a c}^{a c} \cdot Q X A C_{a c}^{-\rho_{c}^{a c}}\right)^{-\frac{1}{\rho_{c}^{a c}-1}}$

$P X A C_{a c}=P X_{c} \cdot Q X_{c}\left(\sum_{a \in A^{\prime}} \delta_{a c}^{a c} \cdot Q X A C_{a c}^{-\rho_{c}^{a c}}\right)^{-1} \cdot \delta_{a c}^{a c} \cdot Q X A C_{a c}^{-\rho_{c}^{a c}-1}$

$P E_{c r}=p w e_{c r} \cdot E X R-\sum_{c^{\prime} \in C T} P Q_{c} \cdot i c e_{c^{\prime} c}$

$Q X_{c}=\alpha_{c}^{t} \cdot\left(\sum_{r} \delta_{c r}^{t} \cdot Q E_{c r}^{\rho_{c}^{t}}+\left(1-\sum_{r} \delta_{c r}^{t}\right) \cdot Q D_{c}^{\rho_{c}^{t}}\right)^{\frac{1}{\rho_{c}^{T}}}$

$\frac{Q E_{c r}}{Q D_{c}}=\left(\frac{P E_{c r}}{P D S_{c}} \cdot \frac{1-\sum_{r} \delta_{c r}^{t}}{\delta_{c}^{t}}\right)^{\frac{1}{\rho_{c}^{t}-1}}$ 
Table A.3. CGE model equations (continued)

\begin{tabular}{|c|c|}
\hline$Q X_{c}=Q D_{c}+\sum_{r} Q E_{c r}$ & (17) \\
\hline$P X_{c} \cdot Q X_{c}=P D S_{c} \cdot Q D_{c}+\sum_{r} P E_{c r} \cdot Q E_{c r}$ & (18) \\
\hline$P D D_{c}=P D S_{c}+\sum_{c^{\prime} \in C T} P Q_{c^{\prime}} \cdot i c d_{c^{\prime} c}$ & (19) \\
\hline$P M_{c r}=p w m_{c r} \cdot\left(1+t m_{c r}\right) \cdot E X R+\sum_{c^{\prime} \in C T} P Q_{c^{\prime}} \cdot i c m_{c^{\prime} c}$ & (20) \\
\hline$Q Q_{c}=\alpha_{c}^{q} \cdot\left(\sum_{r} \delta_{c r}^{q} \cdot Q M_{c r}^{-\rho_{c}^{q}}+\left(1-\sum_{r} \delta_{c r}^{q}\right) \cdot Q D_{c}^{-\rho_{c}^{q}}\right)^{-\frac{1}{\rho_{c}^{q}}}$ & (21) \\
\hline$\frac{Q M_{c r}}{Q D_{c}}=\left(\frac{P D D_{c}}{P M_{c}} \cdot \frac{\delta_{c}^{q}}{1-\sum_{r} \delta_{c r}^{q}}\right)^{\frac{1}{1+\rho_{c}^{q}}}$ & (22) \\
\hline$Q Q_{c}=Q D_{c}+\sum_{r} Q M_{c r}$ & (23) \\
\hline$P Q_{c} \cdot\left(1-t q_{c}\right) \cdot Q Q_{c}=P D D_{c} \cdot Q D_{c}+\sum_{r} P M_{c r} \cdot Q M_{c r}$ & (24) \\
\hline$Q T_{c}=\sum_{c^{\prime} \in C^{\prime}}\left(i c m_{c c^{\prime}} \cdot Q M_{c^{\prime}}+i c e_{c c^{\prime}} \cdot Q E_{c^{\prime}}+i c d_{c c^{\prime}} \cdot Q D_{c^{\prime}}\right)$ & (25) \\
\hline$\overline{C P I}=\sum_{c \in C} P Q_{c} \cdot c w t s_{c}$ & (26) \\
\hline$D P I=\sum_{c \in C} P D S_{c} \cdot d w t s_{c}$ & (27) \\
\hline \multicolumn{2}{|l|}{ Institutional Incomes and Domestic Demand Equations } \\
\hline$Y F_{f}=\sum_{a \in A} W F_{f} \cdot \overline{W F D I S T}_{f a} \cdot Q F_{f a}$ & (28) \\
\hline$Y I F_{i f}=\operatorname{shif}_{i f} \cdot\left[Y F_{f}-t r n s f r_{\text {row } f} \cdot E X R\right]$ & (29) \\
\hline$Y I_{i}=\sum_{f \in F} Y I F_{i f}+\sum_{i^{\prime} \in I N S D N G^{\prime}} T R I I_{i i^{\prime}}+$ trnsfr $_{i g o v} \cdot \overline{C P I}+$ trnsfr $_{\text {irow }} \cdot E X R$ & (30) \\
\hline $\operatorname{TRII}_{i i^{\prime}}=\operatorname{shii}_{i i^{\prime}} \cdot\left(1-\operatorname{MPS}_{i^{\prime}}\right) \cdot\left(1-\overline{\operatorname{tins}}_{i^{\prime}}\right) \cdot Y I_{i^{\prime}}$ & (31) \\
\hline$E H_{h}=\left(1-\sum_{i \in I N S D N G} s h i i_{i h}\right) \cdot\left(1-M P S_{h}\right) \cdot\left(1-\overline{\operatorname{tinS}}_{h}\right) \cdot Y I_{h}$ & (32) \\
\hline$P Q_{c} \cdot Q H_{c h}=P Q_{c} \cdot \gamma_{c h}^{m}+\beta_{c h}^{m} \cdot\left(E H_{h}-\sum_{c^{\prime} \in C} P Q_{c^{\prime}} \cdot \gamma_{c^{\prime} h}^{m}\right)$ & (33) \\
\hline$Q I N V_{c}=I A D J \cdot \overline{\operatorname{qinv}}_{c}$ & (34) \\
\hline$Q G_{c}=\overline{G A D J} \cdot \overline{q g}_{c}$ & (35) \\
\hline$E G=\sum_{c \in C} P Q_{c} \cdot Q G_{c}+\sum_{i \in I N S D N G} t{ }^{\prime} n s f r_{i g o v} \cdot \overline{C P I}$ & (36) \\
\hline
\end{tabular}


Table A.3. CGE Model Equations (continued)

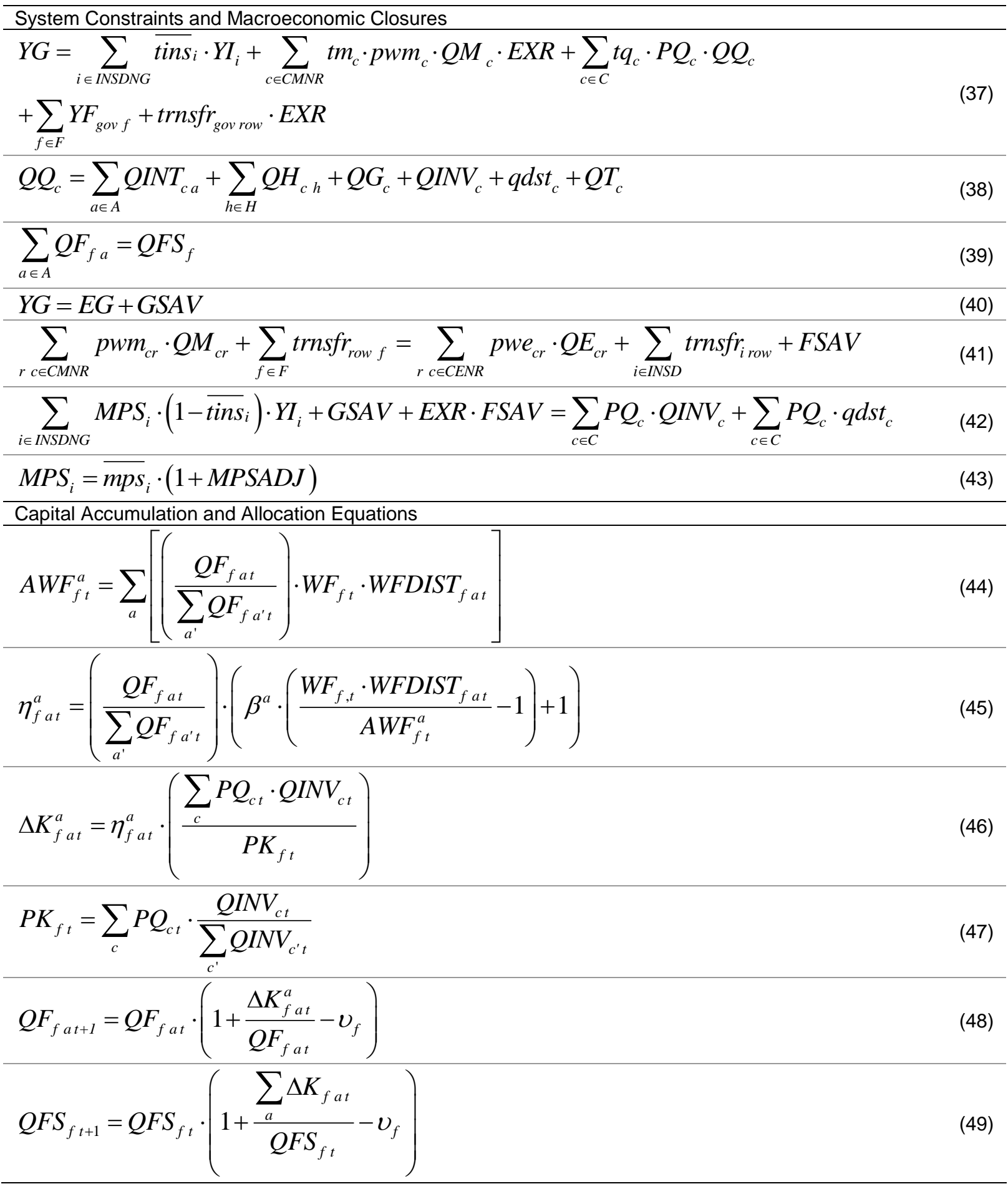

Source: Diao et al. (2011) 


\section{References}

Ethiopian Development Research Institute (EDRI). 2009. Ethiopia: Input Output Table and Social Accounting Matrix for 2005/06. (In collaboration with the Institute of Development Studies at the University of Sussex.) Addis Ababa: EDRI.

Cunguara, B., G. Fagilde, J. Garrett, R. Uaiene, and D. Headey. Forthcoming. "Growth without Change: The Elusiveness of Agricultural and Economic Transformation in Mozambique." Paper presented at the IFPRI-University of Ghana Conference, Understanding Economic Transformation in Sub-Saharan Africa. Accra, Ghana, May 10-11, 2011.

Diao, X., J. Thurlow, S. Benin, and S. Fan, eds. 2011. Strategies and Priorities for African Agriculture: Economywide Perspectives from Country Studies. Washington, D.C.: International Food Policy Research Institute.

Dorosh, P. A, G. Alemu, A. de Brauw, M. Malek, V. Mueller, E. Schmidt, K. Tafere, and J. Thurlow. 2011. The Rural-Urban Transformation in Ethiopia. Ethiopia Strategy Support Program II (ESSPII) and Ethiopian Development Research Institute (EDRI) Report. Addis Ababa: EDRI/ESSP II.

Dorosh, P. A., and J. Thurlow. 2009. Implications of Accelerated Agricultural Growth on Household Incomes and Poverty in Ethiopia: A General Equilibrium Analysis. ESSP II Working Paper 2. Addis Ababa: International Food Policy Research Institute / Ethiopia Strategy Support Program II.

ITU. 2009. Information Society Statistical Profiles 2009 - Africa, International Telecommunication Union (ITU). Ethiopian Telecommunications Corporation (ETC). ETC Strategic Plan. http://www.ethionet.et/aboutus/visionmission.html

Lofgren, H., R. L. Harris, and S. Robinson. 2001. A Standard Computable General Equilibrium (CGE) Model in GAMS. Trade and Macroeconomics Division, Discussion Paper 75. Washington, D.C.: International Food Policy Research Institute.

MOFED. 2010. Growth and Transformation Plan: 2010/11-2014/15. Volume I: Main Text. Addis Ababa: Ministry of Finance and Economic Development (MoFED). Available at: http://www.mofed.gov.et/index.php?option=com_content\&view=article\&id=14\&ltemid $=94$

OECD. 2010. OECD Factbook 2010: Economic, Environmental and Social Statistics. Available at: http://www.oecd-ilibrary.org/sites/factbook-2010en/02/02/03/index.html?contentType=\&itemld=/content/chapter/factbook-2010-14en\&containerltemld=/content/serial/18147364\&accessltemlds=\&mimeType=text/html

Sackey, J., S. Liverpool-Tasie, S. Salau, and T. Awoyemi. Forthcoming. "Rural-Urban Transformation in Nigeria." Paper presented at the IFPRI-University of Ghana Conference Understanding Economic Transformation in Sub-Saharan Africa. Accra, Ghana, May 10-11, 2011.

Schmidt, E. 2011. Unpublished analyses and calculations. International Food Policy Research Institute. Washington, DC.

World Bank. 2010. World Development Indicators 2009. Washington, DC: World Bank. 
INTERNATIONAL FOOD POLICY RESEARCH INSTITUTE 2033 K Street, NW | Washington, DC 20006-1002 USA $\mathrm{T}:+1.202 .862 .5600$ | F: +1.202.457.4439

Skype: ifprihomeoffice | ifpri@cgiar.org | www.ifpri.org

\section{IFPRI-ESSP ADDIS ABABA}

P.O. Box 5689, Addis Ababa, Ethiopia

$\mathrm{T}:+251.11 .617 .2000$ | F: +251.11.646.2318

mahlet.mekuria@cgiar.org | http://essp.ifpri.info
ETHIOPIAN DEVELOPMENT RESEARCH INSTITUTE

P.O. Box 2479, Addis Ababa, Ethiopia

$\mathrm{T}:$ +251.11.550.6066; +251.11.553.8633 | F: +251.11.550.5588

info@edri-eth.org | www.edri-eth.org

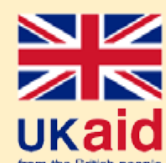

The Ethiopia Strategy Support Program (ESSP) is financially supported by the United States Agency for International Development (USAID) and UK aid from the United

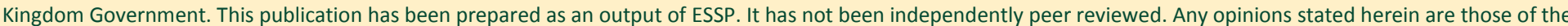

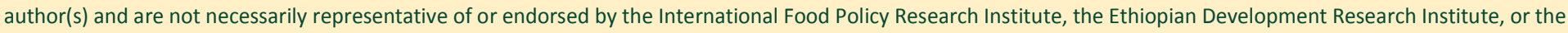
donors.

Copyright (c) 2011 International Food Policy Research Institute. All rights reserved. To obtain permission to republish, contact ifpri-copyright@cgiar.org. 